\title{
Electrical Membrane Properties in the Model Leishmania-Macrophage
}

\author{
Marcela Camacho \\ Universidad Nacional de Colombia, Sede Bogotá, and Centro Internacional de Física \\ Colombia
}

\section{Introduction}

Leishmaniasis, a disease caused by parasites of the genus Leishmania, constitutes a worldwide health problem. Since 1993 the disease has spread over wider areas of the world, and the situation has further deteriorated due to the AIDS pandemic. No vaccine is available to control the disease, and current therapies have problems of resistance, therapeutic failure, and cost (González et al., 2009). In Colombia, the recent incidence of most parasitic diseases has tended to stabilize, but in contrast the last decade has seen a doubling of the incidence of cutaneous Leishmaniasis (INS, 2009). Several reasons explain this, among which climate changes, deforestation, migration, and vector changes are in common with other areas of the world, but local circumstances such as illegal cultivars, the internal armed conflict, and recent health reforms are also important.

The parasite Leishmania transits between different environments in its life cycle, from the mosquito gut to the salivary glands, and for a short period in the vertebrate skin, before entering a compartment known as the parasitophorous vacuole (PV) inside macrophages and dendritic cells. The transformation between the two major parasite stages, from promastigote to amastigote, is the result of some of the changes that occur between the mosquito gut and the $\mathrm{PV}$, among which temperature and $\mathrm{pH}$ have been implicated (Zilberstein \& Shapira, 2004). On the other hand, osmolarity and ionic concentration are known to affect the ability of any cell, presumably including Leishmania, to control membrane potential, ion and nutrient transport, osmolarity, volume, and $\mathrm{pH}$, though the precise effects are yet poorly understood. Our major interest is based on the assumption that Leishmania survival in the macrophage is also the result of the integrated function of the three concentric membranes found by the intracellular (amastigote) form of this parasite: the host cell plasma membrane (i.e., the macrophage plasma membrane), the parasitophorous vacuole membrane (PVM), and the Leishmania plasma membrane.

\section{Macrophage plasma membrane}

In the vertebrate host, Leishmania is an obligatory intracellular parasite that infects cells of macrophagic and dendritic lineage. In other intracellular parasite-host cell relationships, in particular Plasmodium, the demands of the replicating parasite are met by incorporating parasite membrane channels and transporters, or by modulating those of the host cell 
(Ginsburg \& Stein, 2005; Staines et al., 2007; Martin et al., 2009). Altered calcium homeostasis in erythrocytes and muscle cells has been reported in Plasmodium and Trypanosoma infection (Tanabe, 1990; Olivier, 1996; Tardieux et al., 1994) as well as in macrophages infected with Leishmania (Eilam, 1985; Olivier, 1996). Though there is no evidence of Leishmania induced alterations of macrophage nutrient transport, changes in macrophage membrane permeability, particularly in the electrical membrane properties, may alter its ability to activate and present antigen, therefore affecting the immune response.

Several functional activation stages have been proposed for the macrophage (Gordon, 2003; Mosser \& Edwards, 2008). For example, macrophages stimulated in vitro with lipopolysaccharide (LPS) and interferon gamma (INF- $\gamma$ ) activate in a way that has been designated as classical. This functional stage is characterized by morphological changes, increased macrophage surface area, nitric oxide (NO) production, upregulation of tumour necrosis alpha (TNF- $\alpha$ ) secretion, and induction of interleukin 12, among others (reviewed by Gordon, 2003). There is so far no coherent view of macrophage electrical membrane properties and their functional significance and association with the different activation stages, but some associations are now becoming apparent.

\subsection{Macrophage passive membrane properties}

Macrophage passive electrical membrane properties have been recorded in primary macrophages of mouse (Buisman et al., 1988; Vicente et al., 2003), man (Gallin \& Gallin, 1977; Holevinsky \& Nelson, 1998), various mouse (Randriamampita \& Trautmann, 1987; Buisman et al., 1988; Holevinsky \& Nelson, 1998; Gallin, 1991; Forero et al., 1999; Camacho et al., 2008; Quintana et al., 2010; Villalonga et al., 2010) and human (McCann et al., 1987) cell lines. Differences between some measurements of electrophysiological parameters may be related to cell culture conditions, though some authors argue that they represent genuine innate characteristics of currents expressed by macrophages (Randriamampita \& Trautmann, 1987). Several studies support this hypothesis (Randriamampita \& Trautmann, 1987; McKinney \& Gallin, 1990; Forero et al., 1999; Camacho et al., 2008). In this view, variations in characterization are explained by differences in the ionic solutions used and the corresponding change to the Nernst equilibrium and the electrochemical force imposed on each ion, and of course by differences in the ion channel populations expressed (Vicente et al., 2006; Villalonga et al., 2007; Vicente et al., 2008).

In our experience, adherence onto glass, a step used to differentiate monocytes to macrophages, critically affects the electrical properties of these cells. The passive electrical membrane properties of J774.A1, a mouse macrophage-like cell line, vary with time after adherence onto glass, where increased membrane capacitance $(\mathrm{Cm})$ and hyperpolarization have been observed (Gallin \& Sheehy, 1985; McKinney \& Gallin, 1990; Camacho, unpublished data). Active electrical properties also vary, with large outward currents (IOUT) recorded during the first 8 hours post-adherence with minimal inward rectifying current (IKIR) (Gallin \& Sheehy, 1985; Randriamampita \& Trautmann, 1987). IOUT and I $\mathrm{I}_{\mathrm{KIR}}$ have similar amplitudes after 24 hours post-adherence (Gallin \& Sheehy, 1985), but after 48 hours

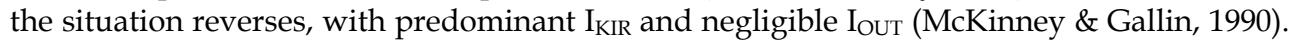
We have therefore controlled for time of adherence onto glass in some of our experiments to guarantee similar amplitudes for IouT and IKIR (Forero et al., 1999; Camacho et al., 2008; Quintana et al., 2010). 
Membrane capacitance is an electrical parameter that is proportional to surface area because the ability to store charge of a capacitor depends on this geometry. The lipid bilayer of the cell membrane can be modelled as a capacitor of two parallel conducting plates separated by a dielectric, so changes in $\mathrm{Cm}$ reflect direct changes in membrane area. $\mathrm{Cm}$ varies with postadherence time (McKinney \& Gallin, 1990) and Leishmania amazonensis post-infection time (Forero et al., 1999; Camacho et al., 2008; Quintana et al., 2010). J774.A1 cells exposed to cytochrome $\mathrm{C}$ to induce apoptosis are smaller than control cells, but have a similar $\mathrm{Cm}$ (Clavijo et al., 2009) suggesting loss of volume without decrease in surface area.

Macrophages are professional phagocytes, and phagocytosis implies the remodelling of the plasma membrane by the cytoskeleton and the incorporation of the phagocytic load into an intracellular compartment, the phagosome (PG). Entry of any load results in plasma membrane donation and should impact macrophage $\mathrm{Cm}$. Phagocytosis of immune complexes or inert particles is associated with a reduction of $\mathrm{Cm}$ proportional to the load. After phagocytosis of $3 \mu \mathrm{m}$ particles, Cm dropped around 7-10\% (Holevinsky \& Nelson, 1998; Quintana et al., 2010). L. amazonensis infected macrophage-like cells lose nearly a third of their Cm by 3 hours post-entry (Quintana et al., 2010), corresponding well to an average parasite load of two to three promastigotes (Hoyos et al., 2009). Cm recovers in this model, and by 24 hours post-infection the values are above control levels (Forero et al., 1999). Membrane donation by the macrophage plasma membrane upon phagocytosis requires recruitment of intracellular membranes from endosomes and lysosomes (Pitt et al., 1992; Desjardins et al., 1994a, Desjardins et al., 1994b, 1995; Beron et al., 1995; Idone et al., 2008). The fusion of these membranes fulfils two purposes: extra membrane for the nascent PG, and early release of immune effectors as shown for TNF- $\alpha$ (Murray et al., 2005, 2005b). Recruitment of endoplasmic reticulum (ER) membrane (Gagnon et al., 2002; Becker et al., 2005) may be important for PG formation when phagocytosing large loads, though this proposed role is controversial. After L. amazonensis entry we observe positive labelling with anti-LAMP antibodies, a lysosomal marker, as well as labelling of PV membranes with anti$\mathrm{IP}_{3}$ receptor (Perez, 2008), a marker of ER, suggesting membrane donation from this organelle.

Other processes in which the macrophage recruits more membrane to the macrophage plasma membrane should polarize more charge and increase $\mathrm{Cm}$. During classical activation, J774.A1 becomes larger and adds membrane (Camacho et al., 2008), but LPS alone surprisingly reduces this parameter in RAW 264.7 (Villalonga et al., 2010), suggesting reduction of surface area. In the Leishmania-macrophage model, evidence of reduction of endosomal and lysosomal compartments (Barbiéri et al., 1990) has been interpreted as a way to concentrate lysosomal activity into the PV to control the parasite. This phenomenon may also indicate alterations in the ratio of membrane fusion/fission in the exocytic/endocytic rate. Assuming that the dielectric properties of J774.A1 plasma membrane do not change during Leishmania infection, the augmentation of macrophage Cm (Forero et al., 1999) may constitute a defect in macrophage plasma membrane recycling.

In most animal cells, the resting $\mathrm{Vm}$ is set by the activity of leak channels selective for $\mathrm{K}^{+}$, along with the contribution of the electrogenic activity of ion pumps. Thus the resting potential of many animal cells is close to $\mathrm{E}_{\mathrm{K}+}$. Most data suggest a Vm for the macrophage close to $\mathrm{E}_{\mathrm{K}+}$ that varies with changes in $\left[\mathrm{K}^{+}\right]_{\mathrm{o}}$ (Gallin \& Sheehy, 1985; Judge et al., 1994). The slope was $-49 \mathrm{mV} / 10$ fold $\left[\mathrm{K}^{+}\right]_{\mathrm{o}}$, indicating higher permeability to $\mathrm{K}^{+}$under resting 
conditions (Gallin \& Sheehy, 1985), but suggesting the contribution of other ions. A contribution of the electrogenic activity of a Na+/ $\mathrm{K}^{+}$ATPase pump (Gallin \& Livengood, 1983 ) of about $6 \mathrm{mV}$ to the macrophage $\mathrm{Vm}$ could explain the deviation found. The depolarization obtained after inhibition of $\mathrm{I}_{\mathrm{KIR}}$ by $\mathrm{Ba}^{2+}$ has implicated this current in the macrophage Vm value (Randriamampita \& Trautmann, 1987), particularly after long periods of adherence (Gallin \& Sheehy, 1985). More recently it has been proposed that Kv1.3 voltage gated channels establish macrophage Vm (Mackenzie et al., 2003) as shown in T lymphocytes (Panyi et al., 2004).

Early measurements of Vm were misinterpreted as action potentials (McCann et al., 1983). Values of around $-75 \mathrm{mV}$ have been recorded (McCann et al., 1987; Gallin \& Sheehy, 1985; Buisman et al., 1988), and it has been suggested that time of adherence is not important because rapid hyperpolarization was observed after only 30 minutes post-adhesion (Gallin \& Sheehy, 1985). Values of -60 to $-70 \mathrm{mV}$ were recorded in $\mathrm{J774}$ and in peritoneal macrophages (Randriamampita \& Trautmann, 1987). In whole cell configuration we have measured Vm when the membrane current is zero during the first minute after attaining this configuration, and have recorded potentials between -40 and $-50 \mathrm{mV}$ (Forero et al., 1999; Camacho et al., 2008; Quintana et al., 2010) at 24 or less hours post-adherence onto glass. Similar values $(-42$ to $-58 \mathrm{mV})$ were reported in the same cell line by McKinney \& Gallin, (1990). In T lymphocytes, Vm is close to the gating potential of Kv1.3 channels and this argument has been used to suggest that one of the functions of this channel is to establish Vm (Panyi et al., 2004). After 24 hours post-phagocytosis the average Vm found was depolarized compared to control macrophages (Camacho et al., 2008). Similar Vm values and depolarizations were found in macrophages stimulated with LPS and INF- $\gamma$ (Camacho et al., 2008) at 24 hours post-treatment or exposed to cytochrome $C$ to induce apoptosis 2 hours post-treatment (Clavijo et al., 2009).

Macrophage membrane resistance $(\mathrm{Rm})$ has been measured. We have found membrane resistance of $2 \mathrm{G} \Omega$ in macrophage-like cells not altered by L. amazonensis infection (Forero et al., 1999). After reaching the whole cell configuration, a $10 \mathrm{mV}$ step pulse was applied to the macrophage from a holding potential of $-60 \mathrm{mV}$ and the recorded current averaged to calculate Rm from Ohm's law. ATP4- exposure reduced $\mathrm{Rm}$ by a factor of 10 in a related macrophage cell line (J774.2), where membrane depolarization was also observed (Buisman et al., 1988). Functional evidence of a poorly selective conductance was recorded, based on the reversal potential measurement $(0 \mathrm{mV}$; Buisman et al., 1988). This is compatible with the permeation effect achieved after the ATP exposure used to load macrophages with anionic fluorescent probes (Steinberg et al., 1987a), explaining the reduction in Rm.

\subsection{Macrophage ion currents}

With respect to active electrical properties of the macrophage plasma membrane, $\mathrm{Cl}^{-}$ currents $\left(\mathrm{I}_{\mathrm{Cl}}\right), \mathrm{K}^{+}$outward $\left(\mathrm{K}^{+} \mathrm{I}_{\mathrm{OUT}}\right)$ and inward currents $\left(\mathrm{I}_{\mathrm{KIR}}\right)$ have been described. Large conductance chloride channels were recorded in patches of J774 and peritoneal macrophages (Randriamampita \& Trautmann, 1987). Thioglycolate-recruited mouse peritoneal cells dialyzed in $\mathrm{K}^{+}$-glutamate containing $\mathrm{InsP}_{3}$ showed a rapidly activating outward current that depolarized the cells, suggesting that part of the current was carried out by $\mathrm{Cl}^{-}$(Judge et al., 1994). In human monocyte-derived macrophages, rises of $\left[\mathrm{Ca}^{2+}\right]_{\mathrm{i}}$ induced an $\mathrm{I}_{\mathrm{Cl}}$ current of properties similar to those described previously, and sensitive to 
DIDS (Holevinsky et al., 1994). A third of the total current recorded in our model was inhibited by DIDS involving an anion, most probably Cl- (Camacho et al., 2008).
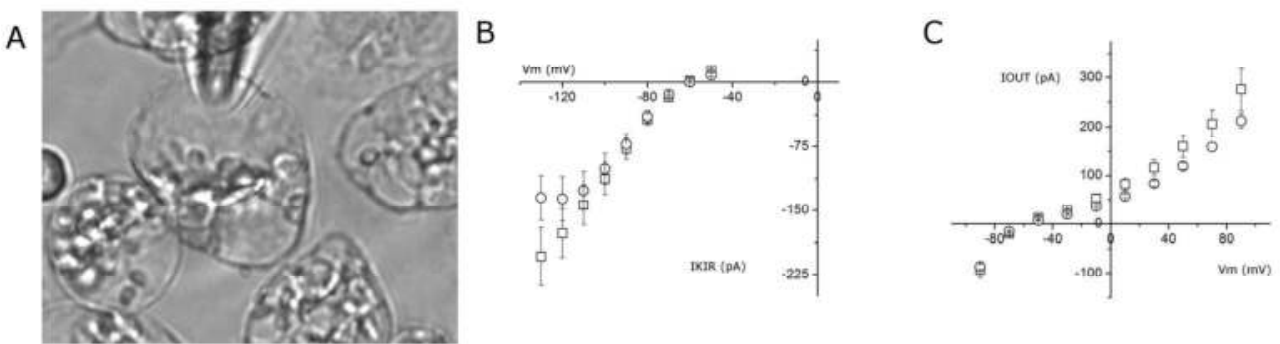

Fig. 1. Currents in J774.A1 macrophage-like cells. A. Light microscopy image of J774.A1 macrophage-like cells infected with Leishmania amazonensis. Note the tip of the recording pipette and the intracellular parasites in the parasitophorous vacuoles. B. I/V curve of inward rectifying potassium currents. C. I/V curve of outward currents. ( $\square$ ) Mean I peak at the beginning of the trace and after the capacitive transient. (O) Mean I of the steady state current in the last $20 \mathrm{~s}$ of the recording. Typical recordings of currents elicited by applying 9-10 pulses of $1 \mathrm{~s}$ (B) or $100 \mathrm{~ms}$ (C) at 10-20 mV intervals, from -50 to $-130 \mathrm{mV}$ (B) or -90 to $90 \mathrm{mV}$ (C) from a holding potential of $-60 \mathrm{mV}$. Data represent the mean values $\pm \mathrm{SE}$ with $\mathrm{n}=10$.

$\mathrm{I}_{\mathrm{KIR}}$ is induced by hyperpolarizing voltages and is inactivating (Gallin \& Sheehy, 1985; Randriamampita \& Trautmann, 1987; McKinney \& Gallin, 1988; Judge et al., 1994; Forero et al., 1999). The voltage range of activation changes to less negative potentials with rises in $\left[\mathrm{K}^{+}\right]_{\mathrm{o}}$, following a square root relation between the peak $\mathrm{G}_{\mathrm{KI}}$ and $\left[\mathrm{K}^{+}\right]_{\mathrm{o}}$ (Gallin and Sheehy, 1985; Randriamampita \& Trautmann, 1987). I KIR inactivation is accelerated by voltage (Gallin \& Sheehy, 1985; Randriamampita \& Trautmann, 1987; Judge et al., 1994; Forero et al., 1999; Figure 1B), and its amplitude inhibited by extracellular $\mathrm{Ba}^{2+}$ (Gallin \& Sheehy, 1985; Randriamampita \& Trautmann, 1987; Forero et al., 1999) and $\mathrm{Cs}^{+}$(Gallin \& Sheehy, 1985; Randriamampita \& Trautmann, 1987; Judge et al., 1994). IKIR goes to zero over time during recording (Gallin and Sheehy, 1985; Randriamampita and Trautmann, 1987), but the current is preserved in time with the addition of ATP and GTP to the pipette solution (McKinney \& Gallin, 1990; Judge et al., 1994), suggesting dependence on metabolism (Judge et al., 1994). $\mathrm{I}_{\mathrm{KIR}}$ was reduced by $\mathrm{H}_{2} \mathrm{O}_{2}$ production (Judge et al., 1994) although the authors did not indicate this. Colony stimulating factor was reported to have no effect on this current (Judge et al., 1994) but more recent data shows induction of this current by macrophage colony stimulating factor (M-CSF; Vicente et al., 2003). Kir2.1 channels are held responsible for this current (Vicente et al., 2003).

$\mathrm{K}^{+}$IOUT appears to be the result of at least three different types of ion channel populations: inactivating, non-inactivating and calcium dependent $\mathrm{K}^{+}$current $\left(\mathrm{Ca}^{2+} \mathrm{K}^{+}\right.$IOUT; Gallin, 1991). Total $\mathrm{K}^{+}$Iout is rapidly activated with depolarization (Figure $1 \mathrm{C}$ ) and inactivates over time. The selectivity was studied in tail currents with different $\left[\mathrm{K}^{+}\right]_{\mathrm{o}}$; the reversal potential was also shifted to lower potentials with rises in $\left[\mathrm{K}^{+}\right]_{\mathrm{o}}$, implicating this ion in these currents (Gallin \& Sheehy, 1985). $\mathrm{K}^{+}$IOUT is inhibited by 4 -aminopyridine (4-AP) and tetraethyl ammonium (TEA; Gallin \& Sheehy, 1985; Camacho et al., 2008;), two classical potassium channel blockers, by margatoxin, a specific inhibitor of $\mathrm{Kv} 1.3$, and by charybdotoxin, a specific inhibitor of calcium dependent potassium channels (Camacho et al., 2008). $\mathrm{Ca}^{2+} \mathrm{K}^{+} \mathrm{I}$ out attains a large amplitude with $\left[\mathrm{Ca}^{2+}\right]_{\mathrm{i}}$ of $1 \mu \mathrm{M}$ and is inhibited by quinine (Randriamampita \& Trautmann, 1987). The 
relative contributions of these currents may however vary with cell type, culture conditions, and cell status (Randriamampita \& Trautmann, 1987; Gallin, 1991; DeCoursey et al., 1996; Eder et al., 1997; Camacho et al., 2008). More recently it has been shown that transcription of specific genes and expression of Kv1.3, Kv1.5 are associated with $\mathrm{K}^{+} \mathrm{I}_{\mathrm{OUT}}$ (Mackenzie et al., 2003; Vicente et al., 2006; Vicente et al., 2006; Park et al., 2006).

Despite several reports that outward currents are altered when macrophages are activated (Nelson et al., 1992; Ichinose et al., 1992; McKinney \& Gallin, 1992), a coherent view of macrophage functional status and electrical membrane properties is just emerging. Using primary cultured cells and a macrophage cell line, Felipe's group initially showed that the majority of the $\mathrm{K}^{+} \mathrm{I}_{\mathrm{OUT}}$ in mouse bone marrow macrophages is generated almost exclusively by Kv1.3 voltage gated potassium ion channels (Vicente et al., 2003). In an elegant set of experiments they characterised the electrophysiological response of these cells and showed $\mathrm{K}^{+}$IOUT and $\mathrm{I}_{\mathrm{KIR}}$. The currents were associated with transcription of mRNA, protein expression, and localization to the macrophage plasma membrane of Kv1.3 and Kir2.1. They showed the expression pattern of these ion channels after stimulation with M-CSF, LPS, and TNF- $\alpha$. Overexpression of Kv1.3 and Kir2.1 translated functionally to approximately three times more $\mathrm{K}^{+}$ $\mathrm{I}_{\mathrm{OUT}}$ and around four times more $\mathrm{I}_{\mathrm{KIR}}$ during macrophage proliferation (M-CSF), contrasting with nearly 15 times more $\mathrm{K}^{+} \mathrm{I}_{\mathrm{OUT}}$ and a reduction to half in $\mathrm{I}_{\mathrm{KIR}}$ after macrophage activation with LPS (classical activation; Vicente et al., 2003). The differences in the timing of mRNA transcription resulted in electrophysiological differences. Furthermore, they recorded evidence of the impact of differential expression of $\operatorname{Kv} \beta$ subunits in macrophages during proliferation and differential activation between LPS and TNF- $\alpha$ (Vicente et al., 2005). The expression of Kv1.5 resulted in associations with Kv1.3 to conform hetero-dimers to distinct biophysical properties (Vicente et al., 2006; Vicente et al., 2007). They also observed modulation by Kv1.5 and LPS of intracellular traffic of Kv1.3 and Kv1.3/Kv1.5 channels (Vicente et al., 2008). Their suggestion is that expression of Kv1.5 does not generate homodimers, but rather the heterodimers Kv1.3/Kv1.5 with different stoichiometries that alter macrophage electrical properties and trafficking to the membrane. In humans, hKv1.5 is transcribed and expressed and a drop is observed in its typical outward current after exposure of antisense oligonucleotides against this channel; functional consequences followed, with a $50 \%$ reduction in migration of human alveolar macrophages (Park et al., 2006). Using the same conditions reported by Vicente et al. (2003), we have amplified products the expected weight for Kir2.1 and $\mathrm{Kv} 1.3$ in J774.A1 cells from mRNA (Figure 2).

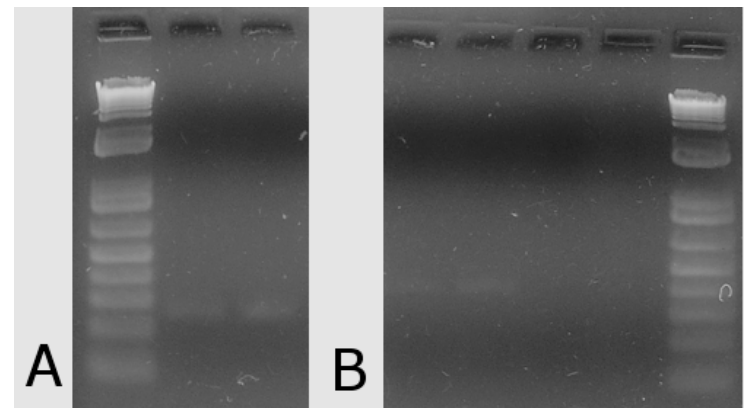

Fig. 2. Transcripts of ion channels in J774.A1. A. Transcripts of the inward rectifier potassium channel Kir2.1. B. Transcripts of the voltage gated potassium ion channel Kv1.3. Primers and PCR conditions are as reported by Vicente et al., (2003). 
TNF- $\alpha$ stimulation alters expression of different $\mathrm{Kv} \beta$, inducing more inactivation of $\mathrm{K}^{+} \mathrm{I}_{\mathrm{OUT}}$ but less expression to the plasma membrane of Kv1.3 after 24 hours compared to LPS stimulation (Vicente et al., 2005). In the mouse macrophage cell line RAW 264.7, there is evidence of transcription, protein expression, protein localization, and functional expression of Kv1.3 and Kv1.5 (Vicente et al., 2006; Villalonga et al., 2007). RAW 264.7 has K+ Iout of smaller amplitude, expresses more Kv1.5 and therefore has less sensitivity to margatoxin (Vicente et al., 2006). Stimulation with LPS of this line resulted in higher transcription and protein expression and increases in $\mathrm{Kv} 1.3 \mathrm{~K}^{+}$IOUT, in contrast to the downregulation in transcription and protein expression and lower $\mathrm{K}^{+}$Iout inactivation after exposure to the immunosuppressor agent dexamethasone (Villalonga et al., 2010). However, it has been suggested that, by inducing Kv1.3 and repressing Kir2.1 after activation, macrophages reduce $\mathrm{Ca}^{2+}$ driving force and intracellular $\mathrm{K}^{+}$concentration (Vicente et al., 2003). In the proposed model of the $\mathrm{T}$ lymphocyte, the influx of $\mathrm{Ca}^{2+}$ after activation depolarizes the membrane and reduces the electrical driving force in the absence of a counterbalancing cation flux, suggesting that Kv1.3 is involved in maintenance of $\mathrm{Ca}^{2+}$ entry (Panyi et al., 2004). A biphasic intracellular increase of calcium has been observed in mouse macrophages. The initial transient is attributed to release of $\mathrm{Ca}^{2+}$ from endoplasmic reticulum, and the second transient, with less amplitude but longer time course, to $\mathrm{Ca}^{2+}$ influx through the plasma membrane (Randriamampita et al., 1991). In TRPV2 (Transient Receptor Potential Vanilloid 2) knockout mice, this cation channel generates a biphasic entry of $\mathrm{Ca}^{2+}$, with a rapid initial transient followed by a sustained increase. The lack of this channel alters macrophage phagocytosis (Link et al., 2010). We have seen evidence of higher $\mathrm{Ca}^{2+}$ concentration in activated macrophage-like cells (Camacho, unpublished data) in which the Vm measured was less than in control cells, suggesting depolarization (Holevinsky \& Nelson, 1995; Camacho et al., 2008). The currents show increased $\mathrm{K}^{+} \mathrm{I}_{\mathrm{OUT}}$ and lowered IKIR (Camacho et al., 2008), similar to the description by Vicente et al., 2003. Thus far unavailable simultaneous measurements of calcium and other potential currents could bolster support for this hypothesis, but a proposal in macrophages similar to that of $\mathrm{T}$ lymphocytes is more coherent. Thus, some of the functional stages of the macrophage (phagocytosis, classical activation) generate an increase in intracellular $\mathrm{Ca}^{2+}$. The entry of this divalent cation depolarizes the membrane, inducing gating of Kv1.3 channels and counterbalancing $\mathrm{Ca}^{2+}$ entry, thereby maintaining the driving force for a sustained response.

We have studied the impact of Leishmania infection on the electrical properties of infected macrophage-like cells using the classical whole cell configuration of the patch clamp technique (Hamill et al., 1981). The model initially chosen was infection of J774.A1 by $L$. amazonensis because this parasite induces a large PV that is easily recognised in a light microscope (Figure 1A). The pipette solution included ATP and GTP to maintain stable currents, particularly $\mathrm{I}_{\mathrm{KIR}}$, and glutamate was the predominant anion (Forero et al., 1999; Camacho et al., 2008; Quintana et al., 2010). The solution flow during pharmacological testing was carefully controlled to avoid rises of the total IOUT (Randriamampita \& Trautmann, 1987). The recordings were easier at earlier times but seal stability was compromised with time post-infection.

Leishmania infection alters macrophage plasma membrane electrical properties and $\mathrm{K}^{+}$ion currents. However, there are differences between the state induced during the first hours post-infection and the state of an established infection of more than 24 hours. Macrophages were seen to depolarize during the first 12 hours post-infection. A decrease in Vm was 
associated with a change in conductance and lower amplitude of $\mathrm{I}_{\mathrm{KIR}}$ density, and a rise of Iout density (Quintana et al., 2009). Reductions of $\mathrm{Cm}$ and depolarization, with similar ion current density, were found in macrophages after phagocytosis of latex beads (Quintana et al., 2009), suggesting that the changes observed during early Leishmania infection are associated with phagocytosis. In contrast, we have shown that an established infection with L. amazonensis of non-activated J774A.1 is associated with increased $\mathrm{I}_{\mathrm{KIR}}$ density (Forero et al., 1999) and a rise in $\mathrm{K}^{+} \mathrm{I}_{\text {OUT }}$ (Camacho et al., 2008), which would tend to counter activation (Vicente et al., 2003) and would be consistent with observed suppression of activation by Leishmania infection (Liew et al., 1998). There is evidence that depolarization is associated with less $\mathrm{I}_{\mathrm{KIR}}$ and a rise in $\mathrm{K}^{+} \mathrm{I}_{\mathrm{OUT}}$, leading to hyperpolarization (Randriamampita \& Trautmann, 1987). The depolarization during early infection (Quintana et al., 2010) can be explained by lower $\mathrm{I}_{\mathrm{KIR}}$, and the hyperpolarization observed in established infection is explained by higher $\mathrm{K}^{+} \mathrm{I}_{\mathrm{OUT}}$ (Camacho et al., 2008).

Scott et al., 2003, working with macrophages stimulated with LPS and INF- $\gamma$, have shown that Leishmania major infection, or treatment with a wide range of $\mathrm{K}^{+}$channel blockers, suppresses NO production, consistent with a role for $\mathrm{K}^{+}$currents in the deactivation effect of Leishmania. We found no differences between non-activated control and infected macrophages in either the $\mathrm{K}^{+}$IOUT density, its Iss/Ip ratio over the period studied, or susceptibility to 4 -AP inhibition. However, the $\mathrm{K}^{+} \mathrm{I}_{\mathrm{OUT}}$ time to peak and sensitivity to TEA were altered by infection, suggesting greater contribution of some potassium channels to the IOUT (Camacho et al., 2008). This is significant because alteration of $\mathrm{K}^{+}$currents may compromise the ability of the macrophage to phagocytose, to be activated (Randriamampita \& Trautmann, 1989; Buchmüller-Rouiller \& Mauël, 1991; Fischer \& Eder, 1995; Holevinsky \& Nelson, 1995; Vicente et al., 2003; Villalonga et al., 2010), to present antigen (McKinney \& Gallin, 1992), and to do transmigration (Gendelman et al., 2009). In particular, inhibition of $\mathrm{K}^{+}$I Out has been associated with reduced phagocytic ability (Hara et al., 1990) and less NO production (Scott et al., 2003; Vicente et al., 2003), suggesting that these currents may be critical in control of infections in macrophages.

Plasma membrane hyperpolarization has been associated with calcium replenishment, production of oxygen radicals (Gamaley et al., 1998; Hattori et al., 2003; Hanley et al., 2004), myoblast membrane fusion (Liu et al., 1998), and protection against apoptosis (Dallaporta et al., 1999; Liu et al., 2005) as well as Leishmania infection (Forero et al., 1999; Fajardo et al., 2007). Leishmania infection raises macrophage intracellular calcium (Eilam et al., 1985; Olivier, 1996), and promotes production of oxygen radicals (Sousa-Franco et al., 2005). Fusion to form giant cells is a physiological response in macrophages (Vignery, 2005; McNally \& Anderson, 2005; Cui et al., 2006) and proceeds via mechanisms similar to those in phagocytosis and with the participation of ER membranes (McNally \& Anderson 2005). There is evidence of protection against apoptosis in macrophages infected with Leishmania (Aga et al., 2002; Lisi et al., 2005). We found that $1 \mu \mathrm{M}$ staurosporin induces apoptosis of J774A.1, but that infection with Leishmania braziliensis protects these cells against this agent. Macrophage apoptosis was accompanied by depolarization of the mitochondrial and macrophage plasma membrane (Clavijo et al., 2009). L. amazonensis and L. braziliensis infection induce macrophage plasma membrane hyperpolarization (Forero et al., 1999; Fajardo et al., 2005). The significance of this hyperpolarization is not clear, though it may contribute to macrophage deactivation. Interestingly, we have observed that the changes in volume of the PV are associated with this membrane potential change (Fajardo et al., 2005). 
We intend to continue with the characterisation of macrophage membrane properties, to understand them in relation to the cell's repertoire of functional stages.

\section{Parasitophorous vacuole membrane}

Leishmania is an intracellular parasitic protozoon of macrophages and dendritic cells, confined in an endolysosomal compartment, the parasitophorous vacuole (PV). Assuming that the parasitophorous vacuole membrane (PVM) permits ion and nutrient exchange between the lumen of the PV and the infected cell cytoplasm, the PVM will be involved in parasite survival and replication. The majority of studies on the biogenesis and membrane composition of phagolysosomes have been made on the model of phagocytosis of latex beads by macrophages (Desjardins \& Griffiths, 2003). These studies have shown highly regulated sequential acquisition into the phagosome of proteins from the plasma, endosomal and lysosomal membranes of the macrophage (Pitt et al., 1992; Desjardins et al., 1994a, 1994b; Desjardins, 1995; Andrews, 1995; Beron et al., 1995; Idone et al., 2008). The compartment is thereby acidified, and with concentrated hydrolytic activity becomes a microbicidal environment. Moreover, once the phagosome (PG) matures to a phagolysosome, enzymatic activity allows protein degradation of intracellular pathogens and coupling of small peptides for antigen presentation in the $\mathrm{MCH}-\mathrm{II}$ context (Harding et al., 1995; Germain, 1995). The correct presentation is vital to orchestrate the immune response. Leishmania delays PG maturation and phagolysosomal formation (Burchmore \& Barrett, 2001). This delay is associated with lipophosphoglycan (LPG), a component of the complex parasite glycocalyx. It has been proposed that LPG disorganises PVM lipid domains and interferes with recruitment of synaptotagmin $\mathrm{V}$, a regulator of the exocytic pathway, delaying the arrival of cathepsin $\mathrm{F}$ and V-Type $\mathrm{H}^{+}$pumps to the PVM (Vinet et al., 2009). The consequence is altered PV enzymatic activity and acidification. Furthermore, Leishmania sequesters in the interface between the PVM and the parasite MCH-II molecules, altering antigen presentation (Antoine et al., 1998).

The permeability of the PVM depends on whether it interacts with the endocytic pathway of the host cell, which varies with different intracellular pathogens (Meirelles \& De Souza, 1983). Toxoplasma gondii PV appears to be excluded from the phagosome maturation process within the endocytic pathway (Lingelbach \& Joiner, 1998). Its PVM comes from host-cell membranes, plasma membrane, ER and mitochondria, in addition to membranes from specialized parasite organelles that appear to interfere with fusion of the PVM with endocytic components (Lingelbach \& Joiner, 1998; Marti et al., 2007). Schwab et al., (1994) have documented bidirectional movement of charged and non-charged molecules of less than 1900 Da between the lumen of the Toxoplasma PV and the host-cell cytoplasm. It has been suggested that this permeability could be involved in nutrient transport, as proposed in Plasmodium where ion channel activity of small cationic and anionic molecules was recorded (Desai et al., 1993; Desai \& Rosenberg, 1997). However, Chlamydia trachomatis PVM, located to the same level in the endocytic pathway as that of Toxoplasma, is able to exclude anionic molecules of low molecular weight (Heinzen \& Hackstadt, 1997), suggesting differences in the transporter repertoire. The molecules described in the PVM of T. gondii and Plasmodium are poorly selective, similar to porin molecules. In the case of Trypanosoma cruzi such molecules are implicated in the lysis of the PVM that sets the parasite free into the host cell cytoplasm (Andrews, 1990). Porin-like molecules that induce ion currents (Noronha 
et al., 2000) have been implicated in Leishmania exit from the macrophage (Horta, 1997; Aleida-Campos \& Horta, 2000).

The Leishmania PV matures in the endosomal pathway to a late endo-lysosomal compartment and has features such as acidic $\mathrm{pH}$, acid phosphatase and hydrolytic activity, and late endosomal and lysosomal membrane markers (Shepherd et al., 1983; Rabinovitch et al., 1985; Prina et al., 1990; Russell et al., 1992; Russell, 1995; Antoine et al., 1998). Despite this apparent hostility, the amastigote is adapted to the $\mathrm{pH}$, and the PV could also be seen as a land of milk and honey since this compartment is rich in products from the degradation of sugars, proteins and nucleic acids (Prina et al., 1990; reviewed by Burchmore \& Barrett, 2001).

The acidification of the PV is assumed to be the result of the V-Type $\mathrm{H}^{+}$pumps in charge of endosomal acidification (Sturgill-Koszycki et al., 1994; Lamb et al., 2009), with a contribution from the parasite metabolism. The pump function may be associated with cationic as well as anionic shunt currents (Harvey \& Wieczorek, 1997; Grabe \& Oster, 2001; Haggie et al., 2007; Carraro-Lacroix et al., 2009; Wienert et al., 2010; Steinberg et al., 2010; Dong et al., 2010) for proper function. In macrophages the presence of the V-Type $\mathrm{H}^{+}$pump is also vital for efficient phagocytosis (Gagnon et al., 2002) and macrophage fusion into giant cells (McNally \& Anderson, 2005).

Leishmania PVM permeability depends on transporters present in the donating membranes: the macrophage plasma membrane (Antoine et al., 1998, Quintana et al., 2009), the endosomal membranes (Veras et al., 1992, 1994, 1995, 1996; Russell et al., 1992; Collins et al., 1997; Schaible et al., 1999; Cortázar et al., 2006), the parasite membrane (Henriques et al., 2003), membrane transporters from the endoplasmic reticulum (Gagnon et al., 2002; Becker et al., 2005; McNally \& Anderson, 2005), and transporters from compartments that exchange membrane with the PVM, endosomes and autophagic vacuoles (Schaible et al., 1999). Thus, the possible membrane transporters present on the PVM include macrophage plasma membrane ion pumps and channels where $\mathrm{K}^{+}$channels (Randriamampita \& Trautmann, 1987; Gallin, 1991; Nelson et al., 1992; Ichinose et al., 1992; McKinney \& Gallin, 1992; Holevinsky \& Nelson, 1995; DeCoursey et al., 1996; Eder et al., 1997; Forero et al., 1999; Scott et al., 2003; Vicente et al., 2003; Mackenzie et al., 2005; Vicente et al., 2006; Park et al., 2006; Hanley et al., 2004; Scheel et al., 2005; Camacho et al., 2008; Villalonga et al., 2010) and transporters of the ABC family (Di et al., 2006) are important. Transporters present in the macrophage intracellular membranes that could contribute to the PV are V-Type $\mathrm{H}^{+}$pumps (Lamb et al., 2009), ionic channels (Dong et al., 2010), $\mathrm{H}^{+}$channels (Grabe \& Hoster, 2001), iron Nramp transporters (Hackam, 1998; Jabado, 2000; Gomez et al., 2007), voltage gated chloride $\mathrm{ClC}$ channel $/ \mathrm{H}^{+}$transporters (Jentsch, 2007; Steinberg et al., 2010; Wienert et al., 2010), and ABC transporters (Russell et al., 1992; Cortázar et al., 2006; Di et al., 2006), not to mention the repertoire of ion channels and pumps present on the ER membrane. The conditions on the PVM in terms of membrane potential, $\mathrm{pH}$ and electrochemical driving force are different for transporters coming from the macrophage membrane, but relatively similar for those coming from intracellular membranes, suggesting that many of the latter are functional.

Several transporters have been found in the Leishmania PVM. The acidification of the compartment is associated with the activity of a V-Type $\mathrm{H}^{+}$pump (Sturgill-Koszycki et al., 1994). The distribution of anionic fluorescent probes of different sizes into in situ and isolated PVs suggests the expression of transporters of the ABC superfamily (Steinberg et 
al., 1987; Russell et al., 1992; Cortázar et al., 2006), which could be involved in nutrient transport or could function as anionic shunts. There are also Narmp1 iron transporters that in some mouse models compromise Leishmania survival (Huynh \& Andrews, 2008).
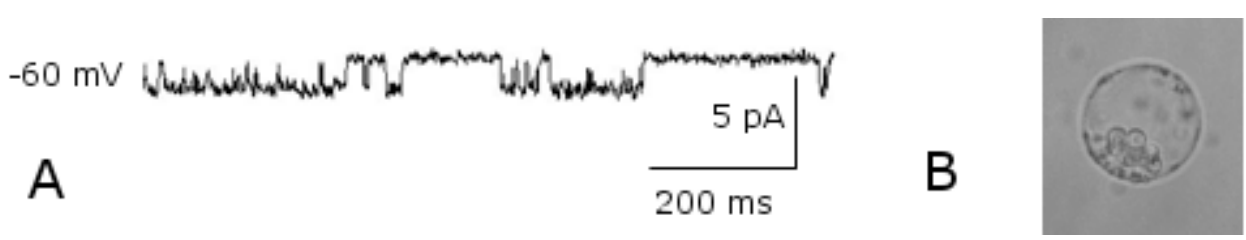

Fig. 3. Patch clamp recording on the parasitophorous vacuole membrane of Leishmania amazonensis. A. Inside-out single channel recording in symmetric solutions consisting of 150 $\mathrm{mM} \mathrm{KCl}, 100 \mu \mathrm{M} \mathrm{CaCl}_{2}$ and $20 \mathrm{mM}$ HEPES, pH 7.2 in the presence of $50 \mu \mathrm{M}$ DIDS. B. Light microscopy of an isolated PV. Note the parasites polarized to the membrane (Perez et al., 2009).

We have recorded ion currents through the PVM (Cortázar et al., 2006; Perez et al., 2009) in the giant PV induced by L. amazonensis in J774.A1 using the PV-attached configuration of the patch clamp technique (Hamill et al., 1981). Isolation of the PV can be achieved by rupturing macrophages with hypotonic solutions and mechanical force (Chakraborty et al., 1994). We substituted a hypotonic solution for an isotonic one in the presence of protein inhibitors and mechanical force (Cortázar et al., 2006), because acidic $\mathrm{pH}$ and probenecid-sensitive Lucifer yellow load were better maintained. Though PV purification can be achieved with either sucrose (Chakraborty et al., 1994) or Percoll gradients (Cortázar et al., 2006), we chose the latter method as in our experience the PV deteriorates in presence of sucrose gradients, most probably due to high osmotic pressure. The purified PV maintains low $\mathrm{pH}$ and $\mathrm{ABC}$ transport activity (Cortázar et al., 2006), though washout of excess Percoll from the PVM has proved difficult, particularly in patch clamp experiments in which seal formation is compromised. We explored the use of differential centrifugation and more recently Split Flow Lateral Transport Thin Cell Fractionation (SPLITT) techniques to enrich the PV fraction, avoiding the problem of further centrifugation and wash (Perez et al., 2007) and preserving the PVM for electrophysiological recording. We used bath solutions with high $\mathrm{Na}^{+}$as well as high $\mathrm{K}^{+}$, with relatively high calcium, and with high $\mathrm{Na}^{+}$in the pipette, and recorded a current with $46 \mathrm{pS}$ conductance in the PV-attached configuration (Cortázar et al., 2006). In high symmetrical $\mathrm{K}^{+}$in the PV-attached configuration there are bursts of anion currents induced by hyperpolarized potentials that are sensitive to broad range anion channel inhibitors but not to probenecid (Perez et al., 2009), ruling out the presence of some ABC transporters. In inside-out patches bathed in high $\mathrm{K}^{+}$and DIDS $50 \mu \mathrm{M}$, cationic single channel activity was recorded that was sensitive to broad range potassium channel blockers (Perez et al., 2009; Figure 3). We are now refining the electrophysiological characterization of these currents before determining the molecular nature of the transporters responsible for them.

\section{Leishmania plasma membrane}

Leishmania adaptation and proliferation during its life cycle demands appropriate regulatory mechanisms for parasite survival. During its life cycle the parasite encounters environmental differences in ion concentrations, osmolarity, $\mathrm{pH}$, temperature and nutrient 
availability, among others. Adaptation to some of these changes requires the expression of ion channels and transporters, and it has been suggested that the parasite will therefore have higher demands for energy (ter Kulle, 1993).

Leishmania relies on purine transport by specific transporters (Ogbunude \& Dzimidi, 1993), has a biopterin transporter capable of also moving folate (Ouellette et al., 2002, Dridi et al., 2010), imports Fe by specific transporters (Huynh et al., 2006; Jacques et al., 2010) to warranty its replication within the PV, and is able to extrude drugs (Ouellette et al., 2001). Of particular importance in Leishmania is the presence of a homologue of the mammalian AQP9 aquaglyceroprotein (Figarella et al., 2007) associated with parasite resistance to one of the first line therapies (Gourbal, 2004; Figarella et al., 2007; Maharjan et al., 2008). LmAQP1 has been shown to contribute to parasite water and glycerol transport (Figarella et al., 2007). More recently a family of aquaporins was described in Leishmania donovani. They localise intracellularly, have differential expression, and can potentially contribute to parasite osmolarity regulation by transporting water because once transfected into yeast they alter the osmolarity properties of these cells (Biyani et al., 2011).

Molecules involved in nutrient uptake are found in Trypanosomatidae (Glaser \& Mukkada, 1992; ter Kulle, 1993; Vieira et al., 1996; Tetaud et al., 1994). Transport of D-glucose and Dproline is mediated by $\mathrm{H}^{+}$symporters in Leishmania (Zilberstein \& Dwyer, 1985; Zilberstein, 1993). The transport of 2-deoxy-D-glucose was used as a measure of D-glucose and it was shown that Leishmania donovani secondarily transports glucose. Glucose can be concentrated to a level of about 80 times the extracellular concentration by an electrochemical gradient of protons (Zilberstein \& Dwyer, 1985). Sucrose is similarly concentrated by a sucrose $/ \mathrm{H}^{+}$ symporter in promastigotes of L. donovani (Singh \& Mandal, 2011) and forms a potential source of nutrients relevant for this form living in the mosquito gut. Arginine is an essential amino acid for Leishmania. Leishmania donovani LdAAP3 permease has highly specific arginine transport activity in Saccharomyces cerevisiae, optimal at low $\mathrm{pH}$, and when coupled to GFP localises to the Leishmania plasma membrane (Shaked-Mishan et al., 2006). Lysine is an essential amino acid of many eukaryotes including Leishmania. Unlike mammalian cells, Leishmania has independent permeases for arginine and lysine. LdAAP7 expressed in $S$. cerevisiae transports lysine, but when over-expressed in promastigotes has no impact on the uptake of this amino acid (Inbar et al., 2010). LdAA7 is essential for parasite survival and localises to the promastigote plasma membrane and flagella (Inbar et al., 2010).

Leishmania as other eukaryotes is capable of maintaining lower levels of cytoplasmic $\mathrm{Ca}^{2+}$. The parasite stores this ion in the usual compartments, the ER and mitochondria (Philosoph \& Zilberstein, 1989), but also in specialized vesicles, the acidocalcisomes (Lu et al., 1997), which are important during parasite invasion, differentiation and replication (Moreno \& Docampo, 2003). Evidence suggests that calmodulin (Moreno \& Docampo, 2003) and calcium ATPases are present in the ER membrane (Philosoph \& Zilberstein, 1989) and in the Leishmania plasma membrane (Mandal et al., 1997; Corte-Real et al., 1995), where they will pump calcium out of the parasite cytoplasm. In addition to controlling calcium, Leishmania controls volume and osmolarity. The parasite transits from the insect gut, where fluctuations in osmolarity are expected, to the PV, which is believed to be hypo-osmotic compared to the macrophage cytoplasm (LeFurgey et al., 2005). In hypotonic solutions, water enters Leishmania, increasing its volume, which is later restored to normal levels. The recovery is associated with extrusion of ions, saccharides and amino acids (Darling et al., 1990; 
LeFurgey et al., 2005), as well as with minor changes of $\mathrm{K}^{+}$and efflux of alanine through a DIDS sensitive transporter that alters Vm (Vieira et al., 1996). This latter transporter possesses ion channel kinetics (Vieria et al., 1996) and is regulated by protein kinases A and $C$ and arachidonic acid (Vieira et al., 1997). In addition to acidocalcisomes, other intracellular organelles may be involved, by moving $\mathrm{Na}^{+}$and $\mathrm{Cl}^{-}$(LeFurgey et al., 2001). Leishmania also maintains a large pool of free intracellular amino acids that appears to help the parasite to respond to osmolarity changes (Shaked-Mishan et al., 2006).

Ion and nutrient transport are fundamental in all cells for function and survival. Cells build up ion gradients by investing energy, generating an electrochemical force that when dissipated allows secondary transport of ions, sugars and amino acids and indirect regulation of volume, $\mathrm{pH}$ and osmolarity. In eukaryotic cells the pumps that acidify in the endocytic pathway are V-Type (Lamb et al., 2009). $\mathrm{H}^{+}$concentration induces a proton motive force that opposes further acidification. Cationic and anionic shunt currents present in the endocytic membranes counteract the effect of this force on pump function (Harvey \& Wieczorek, 1997; Graben \& Oster, 2001; Scheel et al., 2005; Carraro-Lacroix et al., 2009; Wienert et al., 2010; Steinberg et al., 2010; Dong et al., 2010). Recent evidence suggests that anion entry may not be required for maintenance of the electromotive force for pump functioning and, surprisingly, that the $\mathrm{H}^{+}$gradient may serve to concentrate $\mathrm{Cl}^{-}$that might be important in the progression in the endocytic pathway (Novarino et al., 2010). The maintenance of intracellular $\mathrm{pH}$ within the physiological range is important in this parasite, particularly when adapting to the low pH of the PV (Antoine et al., 1990). The acidification of the PV results from V-Type $\mathrm{H}^{+}$pump activity (Sturgill-Koszycki et al., 1994) coupled to anionic or cationic currents. In macrophages, the currents generated by chloride channels CFRT (Di et al., 2006) and $\mathrm{ClC} / \mathrm{H}^{+}$transporters (Steinberg et al., 2010) are the candidate anion current shunts.

Leishmania maintains an intracellular $\mathrm{pH}$ that ranges between 6.4 and 6.8 (Vieira et al., 1994; Marchesini \& Docampo, 2002) independent of the environmental pH. Amastigotes show tighter $\mathrm{pH}$ regulation compared to promastigotes (Marchesini \& Docampo, 2002). In promastigotes, the insect form, a proton electrochemical gradient drives secondary transport of D-glucose and D-proline (Zilberstein \& Dwyer, 1985); this gradient is built up by the activity of P-type $\mathrm{K}^{+} / \mathrm{H}^{+}$pumps that are $\mathrm{Mg}^{2+}$ dependent and orthovanadate sensitive (Jiang et al., 1994; Mukherjee et al., 2001; Burchmore \& Barrett, 2001). This pump indirectly effects $\mathrm{pH}$ regulation by keeping the chemiosmotic energy constant (Zilberstein, 1993). Two P-Type $\mathrm{H}^{+}$pumps have been cloned with differential expression between amastigotes and promastigotes (Meade et al., 1987), one of which is expressed on the parasite plasma membrane (Anderson \& Mukkada, 1994; Marchesini \& Docampo, 2002). Functional complementation of $S$. cerevisiae with the putative P-Type $\mathrm{H}^{+}$pumps LDH1A and LDH1B induces an electrochemical gradient and allows survival of this yeast at low $\mathrm{pH}$ (Grigore \& Meade, 2006).

Other pumps and transporters are also found in Leishmania membranes. A different $\mathrm{H}^{+}$ pump has been suggested in Leishmania $\mathrm{pH}$ regulation. The use of DCCD has implicated $\mathrm{H}^{+}$ pump activity in parasite $\mathrm{pH}$ control. It has been suggested that, in Leishmania major promastigotes, a $\mathrm{H}^{+}$pump and a $\mathrm{Cl}^{-}$channel contribute to acid secretion and to the maintenance of a hyperpolarized membrane potential (Vieira et al., 1994; Vieira et al., 1995). These authors refer to the inhibition of a $\mathrm{H}^{+}$pump by the use of DCCD, which is more 
compatible with the V-PP- $\mathrm{H}^{+}$pump (vacuolar proton-pumping pyrophosphatase) described in plants and protozoa. The $\mathrm{V}-\mathrm{PP}-\mathrm{H}^{+}$pump activity of digitonin-permeabilized L. donovani promastigotes is $\mathrm{K}^{+}$dependent, and inhibited by $\mathrm{Na}^{+}$, DCCD and $\mathrm{N}$-ethylmaleimide, but not by vanadate (a P-Type $\mathrm{H}^{+}$pump inhibitor) or bafilomycin-A (a V-Type $\mathrm{H}^{+}$pump inhibitor). The pump localises to subfractions of electron-dense organelles with contents similar to acidocalcisomes, and it is suggested that it acts to degrade cytosolic pyrophosphatase (Rodrigues et al., 1999). Docampos' group later described, in amastigotes of L. amazonensis, a $\mathrm{H}^{+}$pump sensitive to DCCD and N-ethylmaleimide but not to bafilomycin-A; based on its apparent $\mathrm{K}^{+}$independence, they concluded it has P-Type $\mathrm{H}^{+}$pump activity. The positive labelling of the parasite plasma membrane with antibodies against the TcHA2 of Trypanosoma, that recognises LDH1 in promastigotes and amastigotes, suggests that the $\mathrm{H}^{+}$ pump seen by them is the P-Type $\mathrm{H}^{+}$pump described by Zilberstein's group and cloned by Meade's group, but the activity reported corresponds to the V-PP- $\mathrm{H}^{+}$pump described by Rodrigues et al., 1999. Besides the two type pumps, a $\mathrm{Na}^{+} / \mathrm{K}^{+}$pump has been suggested on the Leishmania mexicana plasma membrane based on ouabain sensitivity (Felibertt et al., 1995). Also P-type $\mathrm{K}^{+}$and a $\mathrm{Na}^{+}$pumps (Stiles et al., 2003), $\mathrm{Na}^{+} / \mathrm{H}^{+}$exchanger (Vercesi et al., 2000) and $\mathrm{Mg}^{2+} / \mathrm{H}^{+}$pump activities were found in $L$. donovani. The antiporter accumulates $\mathrm{H}^{+}$in everted vesicles in the presence of ATP and $\mathrm{Mg}^{2+}$, releases it when exposed to FCCF, and is unable to transport $\mathrm{Rb}^{+}$, therefore implicating $\mathrm{Mg}^{2+}$ as the co-transported ion (Mukherjee et al., 2001).

Leishmania $\mathrm{Vm}$ has been measured in promastigotes and amastigotes. Very hyperpolarized Vm values are found (-113 mV; Vieira et al., 1995; Marchesini \& Docampo, 2002) after bisoxonol distribution in promastigotes, and less hyperpolarized $\mathrm{Vm}$ are found in amastigotes (-75 mV; Marchesini \& Docampo, 2002). The activity of DCCD on the electrochemical gradient created by $\mathrm{H}^{+}$pumps coupled to DIDS sensitive anion transporters have been implicated in the promastigote Vm (Vieira et al., 1995; Marchesini \& Docampo 2002) and Vieira et al., (1995), concluded that there is no contribution from $\mathrm{K}^{+}$or $\mathrm{Na}^{+}$to the Leishmania Vm, despite previous data where distribution of tetraphenylphosphonium bromide points to $\mathrm{K}^{+}$(Glaser et al., 1992) as in other eukaryotes. Again the presumed DCCD-sensitive $\mathrm{H}^{+}$pump activity was shown in intracellular compartments of Leishmania promastigotes, but the proposed model couples its function to DIDS sensitive transporters on the parasite plasma membrane.

Direct measure of an anion conductance was recorded in plasma membranes of Leishmania mexicana reconstituted in lipid planar bilayers (DiFranco et al., 1995). These authors described two anionic currents but suggested the presence of other channels. Their finding is consistent with Leishmania anion fluxes involved in parasite survival (Ponte-Sucre et al., 1998) and electron transport by redox enzymes (Bera et al., 2005). We have been interested in the study of ion channels of Leishmania, with a particular emphasis on chloride channels, assuming that these molecules are relevant in parasite survival and are an adaptation to the acidic $\mathrm{pH}$ of the PV. Direct recordings on the parasite have not been possible due to its small size, shape, movement, and the presence of a complex glycocalyx on its surface that interferes with seal formation. To overcome this difficulty we have used amphibian oocytes to express total mRNA from Leishmania. In combination with the model of Xenopus oocytes (Stühmer, 1992) we have shown that other species are capable of expressing ion channels efficiently (Bufo marinus). However, we have encountered some difficulties in both models in particular low oocyte production and viability compared to other reports (Chaves et al., 
2003). We attribute these to reduced partial oxygen pressure due to the altitude of Bogotá ( $2600 \mathrm{~m}$ above sea level) where the laboratory is located, because control of temperature and hormone replacement did not improve production or oocyte viability (Arroyo \& Camacho, 2006). Despite these difficulties it is possible to record the expected potassium currents after injection of cRNA of the ion channel Kv1.1 (Vargas et al., 2004).
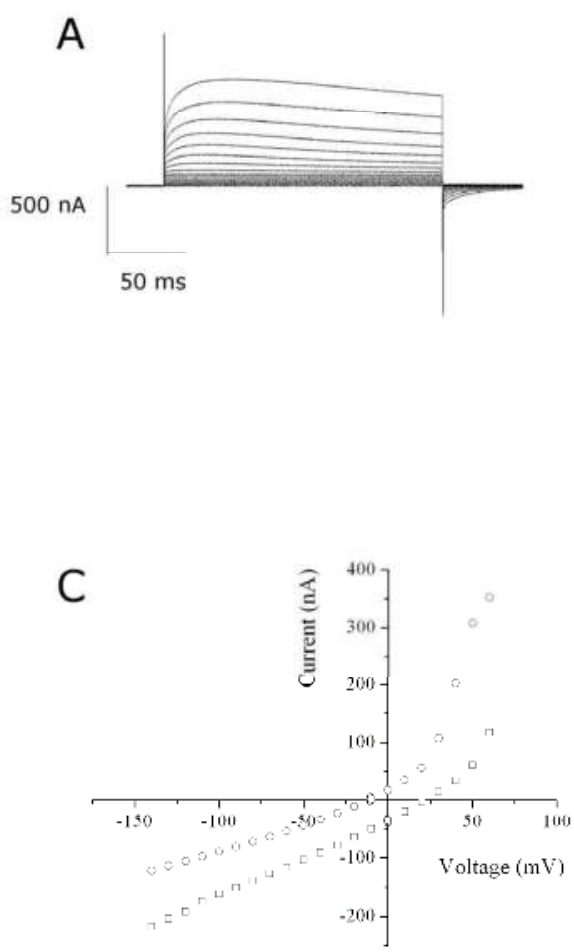
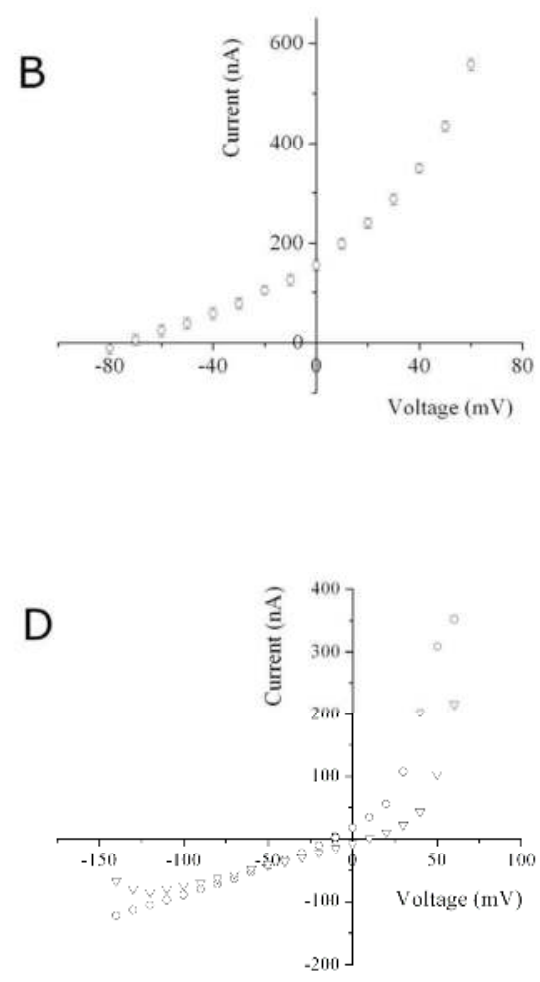

Fig. 4. Two electrode voltage clamp currents of Bufo marinus oocytes. A. A representative current recording. Whole cell membrane currents were recorded from a holding potential of $-80 \mathrm{mV}$. Pulses were applied with $10 \mathrm{mV}$ steps during 0.5 seconds. B. Mean I/V curves of control oocytes. C. Inhibition of control currents in the presence of DIDS. D. Inhibition of control currents in the presence of EGTA. Mean current of control oocytes, $\square$ ) DIDS and (D) EGTA (Arroyo, 2005).

B. marinus can be kept in captivity at intermediate altitudes (e.g. in Bogotá) in controlled temperature environments and 12 hour light cycles. They can be fed with insects or earthworms, and oocyte production can be induced with gonadotropic hormone (Arroyo \& Camacho, 2006). The basal oocyte ion currents of B. marinus recorded with two-electrode voltage clamp are mainly due to chloride. The reversal potential of the currents is close to the chloride equilibrium potential, which becomes more negative in chloride-free medium, suggesting that potassium permeability is also important (Figure 4). The currents are sensitive to broad anion inhibitors of these channels such as DIDS, which caused the 
inhibition (Figure 4C). These currents are also calcium dependent because recording in the presence of the chelator EGTA reduces their current amplitude (Figure 4D). The electrophysiological properties found resemble those of the currents described for X. laevis oocytes (Miledi et al., 1989).

Using X. laevis and B. marinus oocytes we have studied the ion currents induced after injection of polyA mRNA of L. amazonensis (Arroyo, 2005; Lagos et al., 2007) and Leishmania braziliensis (Garzon et al., 2009). We recorded three types of chloride currents, one of which (Type 3) appears to be specific to parasite mRNA injection. Type 3 currents were characterized by a slow activation to a stationary level, without any inactivation. Reduction of extracellular $\mathrm{Cl}^{-}$resulted in an altered current, indicating that the current was mediated by chloride ions. Substitution of extracellular $\mathrm{Cl}^{-}$by other halogens indicated a relative anion permeability sequence $\mathrm{I}->\mathrm{Br}^{-}>\mathrm{Cl}^{-}$. Negative results with the broad spectrum $\mathrm{K}^{+}$ channel inhibitors TEA and 4-AP eliminated the possibility of contribution of $\mathrm{K}^{+}$currents. Conversely, these currents showed sensitivity to the broad spectrum $\mathrm{Cl}^{-}$channel blockers DIDS and niflumic acid; one-third of the current was blocked by these two inhibitors. Reduction of extracellular divalent cations using a nominally $\mathrm{Ca}^{2+}$-free solution with $1 \mathrm{mM}$ EGTA resulted in only a 10\% decrease of the amplitude of this current (Lagos et al., 2007). There are several classes of chloride channels and three molecularly distinct chloride channel families (ClC, CFTR and ligand-gated GABA and glycine receptors; Jentsch et al., 2005). In animal cells, the activity of $\mathrm{V}$-Type $\mathrm{H}^{+}$pumps in endosomal compartments is associated with $\mathrm{ClC}$ chloride channel activity.
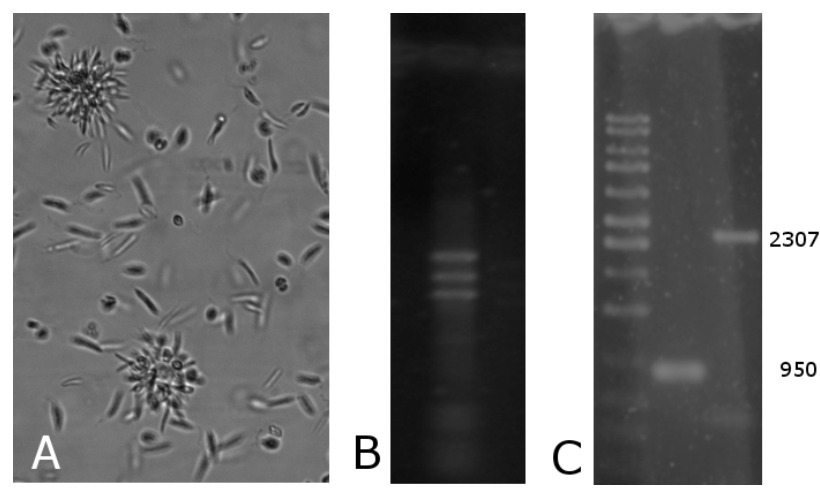

Fig. 5. Transcription of the putative chloride channel LbrM01 V2.0210. A. Promastigotes of Leishmania braziliensis. Note typical rosettes. B. Total RNA of Leishmania. A triple band of ribosomal RNA is found and is typical of this parasite. Agarose gel of a partial and total product of the putative $\mathrm{ClC}$ channel (Lozano et al., 2009).

The Leishmania amastigote inside the PV is constantly flooded by protons, and $\mathrm{ClC}$ channel/ $\mathrm{H}^{+}$ transporter expression will contribute to efflux of $\mathrm{H}^{+}$, alleviating $\mathrm{pH}$ changes, and may concentrate $\mathrm{Cl}^{-}$or other relevant anions. With the information available on the L. braziliensis genome we have identified four potential putative genes for chloride channels, one of which is classified as $\mathrm{ClC}$. We have recently cloned the putative $\mathrm{ClC}$ channel of L. braziliensis (Lozano et al., 2009; Figure 5) which is homologous to intracellular mammalian $\mathrm{ClC}$ channels, some of which are co-transporters of $\mathrm{Cl}-/ \mathrm{H}^{+}$. We have inserted this putative channel into an expression 
vector and recorded HEK293 cells with patch clamp in the whole-cell configuration after transfection of LbrM01 V2.0210. A Cl- current 10 times the amplitude of control currents was recorded (Lozano et al., 2011). We are further characterising this channel and hope to understand its importance for Leishmania physiology.

\section{Acknowledgement}

The author thanks the Departamento de Biología, Facultad de Ciencias, Universidad Nacional de Colombia, Sede Bogotá, and the Laboratorio de Biofísica, Centro Internacional de Física; the Colombian agency Colciencias (projects 222852129302, 222851928951 and 2228519289191); and the División de Investigación de Bogotá, DIB, Universidad Nacional de Colombia, Sede Bogotá. The author wants to thank Michel Delay, INDEC Systems, Inc., who kindly edited this manuscript.

\section{References}

Aga E, Katschinski DM, van Zandbergen G, Laufs H, Hansen B, Müller K, Solbach W, Laskay $\mathrm{T}$. Inhibition of the spontaneous apoptosis of neutrophil granulocytes by the intracellular parasite Leishmania major. J Immunol. 2002;169(2):898-905.

Almeida-Campos FR, Horta MF. Proteolytic activation of leishporin: evidence that Leishmania amazonensis and Leishmania guyanensis have distinct inactive forms. Mol Biochem Parasitol. 2000;111(2):363-375.

Anderson SA, Mukkada AJ. Biochemical and immunochemical characterization of a P-type ATPase from Leishmania donovani promastigote plasma membrane. Biochim Biophys Acta. 1994 ;1195(1):71-80.

Andrews NW. The acid-active hemolysin of Trypanosoma cruzi. Exp Parasitol. 1990;71(2):241-4.

Andrews NW. Lysosome recruitment during host cell invasion by Trypanosoma cruzi. Trends Cell Biol. 1995;5:133-137

Antoine JC, Prina E, Jouanne C, Bongrand P. Parasitophorous vacuoles of Leishmania amazonensis-infected macrophages maintain an acidic $\mathrm{pH}$. Infect Immun. 1990;58(3):779-787.

Antoine JC, Prina E, Lang T, Courret N. The biogenesis and properties of the parasitophorous vacuoles that harbour Leishmania in murine macrophages. Trends Microbiol. 1998;6(10):392-401.

Arroyo R. Expresión heteróloga de ARNm poli(A)+ de Leishmania (Trypanosomatidae) en ovocitos de anfibio (Bufonidae), Departamento de Biología, Facultad de Ciencias, Universidad Nacional de Colombia; 2005

Arroyo R, Camacho M. Generación de una colonia de Chaunus marinus como fuente de ovocitos para estudios electrofisiológicos. Tema Zoocría. II Congreso colombiano de zoología; 2006:557.

Barbiéri CL, Doine AI, Freymuller E. Lysosomal depletion in macrophages from spleen and foot lesions of Leishmania-infected hamster. Exp Parasitol. 1990;71(2):218-28.

Becker T, Volchuk A, Rothman JE. Differential use of endoplasmic reticulum membrane for phagocytosis in J774 macrophages. Proc Natl Acad Sci U S A. 2005;102(11):4022-6.

Bera T, Lakshman K, Ghanteswari D, Pal S, Sudhahar D, Islam MN, Bhuyan NR, Das P. Characterization of the redox components of transplasma membrane electron 
transport system from Leishmania donovani promastigotes. Biochim Biophys Acta. 2005;1725(3):314-326.

Beron W, Alvarez-Dominguez C, Mayorga L, Stahl PD. Membrane trafficking along the phagocytic pathway. Trends Cell Biol. 1995;5:100-104

Biyani N, Mandal S, Seth C, Saint M, Natarajan K, Ghosh I, Madhubala R. Characterization of Leishmania donovani Aquaporins Shows Presence of Subcellular Aquaporins Similar to Tonoplast Intrinsic Proteins of Plants. PLoS One. 2011;6(9):e24820.

Buisman HP, Steinberg TH, Fischbarg J, Silverstein SC, Vogelzang SA, Ince C, Ypey DL, Leijh PC. Extracellular ATP induces a large nonselective conductance in macrophage plasma membranes. Proc Natl Acad Sci U S A. 1988;85(21):7988-92.

Burchmore RJ, Barrett MP. Life in vacuoles--nutrient acquisition by Leishmania amastigotes. Int J Parasitol. 2001;31(12):1311-20.

Buchmüller-Rouiller Y, Mauël J. Macrophage activation for intracellular killing as induced by calcium ionophore. Correlation with biologic and biochemical events. J Immunol. 1991;146(1):217-223.

Chakraborty P, Sturgill-Koszycki S, Russell DG. Isolation and characterization of pathogencontaining phagosomes. Methods Cell Biol. 1994;45:261-276.

Chaves H, Villalba C, Lagos L, Vargas R, Martínez-Wittinghan F, Clavijo C, Camacho M. Expresión de canales de potasio voltaje dependientes en ovocitos de Xenopus laevis (amphibia) Acta biol Colomb. 2003;8(1):59-67.

Clavijo LM, Forero ME, Matta NE, Camacho M. Impacto de la infección de L. (V.) braziliensis sobre apoptosis y propiedades eléctricas de macrófagos. Biomedica. 2009;29(S)351.

Camacho M, Forero ME, Fajardo C, Niño A, Morales P, Campos H. Leishmania amazonensis infection may affect the ability of the host macrophage to be activated by altering their outward potassium currents. Exp Parasitol. 2008;120(1):50-6.

Carraro-Lacroix LR, Lessa LM, Fernandez R, Malnic G. Physiological implications of the regulation of vacuolar H+-ATPase by chloride ions. Braz J Med Biol Res. 2009;42(2):155-163.

Collins HL, Schaible UE, Ernst JD, Russell DG. Transfer of phagocytosed particles to the parasitophorous vacuole of Leishmania mexicana is a transient phenomenon preceding the acquisition of annexin I by the phagosome. J Cell Sci. 1997;110 (Pt 2):191-200.

Cortázar TM, Hernández J, Echeverry MC, Camacho M. Role of the parasitophorous vacuole of murine macrophages infected with Leishmania amazonensis in molecule acquisition. Biomedica. 2006;26;S1:26-37.

Corte-Real S, Santos CB, Meirelles MN. Differential expression of the plasma membrane $\mathrm{Mg} 2+$ ATPase and $\mathrm{Ca} 2+$ ATPase activity during adhesion and interiorization of Leishmania amazonensis in fibroblasts in vitro. J Submicrosc Cytol Pathol. 1995;27(3):359-366.

Cui W, Ke JZ, Zhang Q, Ke HZ, Chalouni C, Vignery A.The intracellular domain of CD44 promotes the fusion of macrophages. Blood. 2006;107(2):796-805.

Dallaporta B, Marchetti P, de Pablo MA, Maisse C, Duc HT, Métivier D, Zamzami N, Geuskens M, Kroemer G. Plasma membrane potential in thymocyte apoptosis. J Immunol. 1999;162(11):6534-65G42.

DeCoursey TE, Kim SY, Silver MR, Quandt FN. Ion channel expression in PMAdifferentiated human THP-1 macrophages. J Membr Biol. 1996;152(2):141-57. 
Darling T N, Burrows CM, Blum JJ. Rapid shape change and release of ninhydrin-positive substances by Leishmania major promastigotes in response to hypo-osmotic stress. J Protozool. 1990;37:493-499.

Desai SA, Krogstad DJ, McCleskey EW. A nutrient-permeable channel on the intraerythrocytic malaria parasite. Nature. 1993;362(6421):643-646.

Desai SA, Rosenberg RL. Pore size of the malaria parasite's nutrient channel. Proc Natl Acad Sci U S A. 1997;94(5):2045-2049.

Desjardins M, Celis JE, van Meer G, Dieplinger H, Jahraus A, Griffiths G, Huber LA. Molecular characterization of phagosomes. J Biol Chem. 1994a;269(51):32194-32200.

Desjardins M, Huber LA, Parton RG, Griffiths G. Biogenesis of phagolysosomes proceeds through a sequential series of interactions with the endocytic apparatus. J Cell Biol. 1994b;124(5):677-688.

Desjardins M. Biogenesis of phagolysosomes: the 'kiss and run' hypothesis.Trends Cell Biol. 1995;5(5):183-186.

Desjardins M, Griffiths G. Phagocytosis: latex leads the way. Curr Opin Cell Biol. 2003;15(4):498-503.

Di A, Brown ME, Deriy LV, Li C, Szeto FL, Chen Y, Huang P, Tong J, Naren AP, Bindokas V, Palfrey HC, Nelson DJ. CFTR regulates phagosome acidification in macrophages and alters bactericidal activity. Nat Cell Biol. 2006;8(9):933-944.

Dridi L, Ahmed Ouameur A, Ouellette M. High affinity S-Adenosylmethionine plasma membrane transporter of Leishmania is a member of the folate biopterin transporter (FBT) family. J Biol Chem. 2010;285(26):19767-19775.

DiFranco M, Villarroel A, Ponte-Sucre A, Quinonez M, Drujan D, Dagger F. Incorporation of ion channels from the plasma membrane of Leishmania mexicana into planar bilayers. Acta Cient Venez. 1995;46(3):206-207.

Dong XP, Wang $\mathrm{X}, \mathrm{Xu} \mathrm{H}$. TRP channels of intracellular membranes. J Neurochem. 2010;113(2):313-328.

Eder C, Klee R, Heinemann U. Pharmacological properties of Ca2+-activated K+ currents of ramified murine brain macrophages. Naunyn Schmiedebergs Arch Pharmacol. 1997;356(2):233-239.

Eilam Y, El-On J, Spira DT. Leishmania major excreted factor, calcium ions and the survival of amastigotes. Exp Parasitol. 1985;59(2):161-168.

Fajardo C, Villota Y, Forero ME, Camacho M. La infección por Leishmania promueve desactivación del macrófago y esto se ve reflejado en las propiedades eléctricas de la célula hospedera. Biomedica. 2007; 27(S2):146.

Felibertt P, Bermúdez R, Cervino V, Dawidowicz K, Dagger F, Proverbio T, Marín R, Benaim G. Ouabain-sensitive $\mathrm{Na}+, \mathrm{K}(+)$-ATPase in the plasma membrane of Leishmania mexicana. Mol Biochem Parasitol. 1995;74(2):179-87.

Figarella K, Uzcategui NL, Zhou Y, LeFurgey A, Ouellette M, Bhattacharjee H, Mukhopadhyay R. Biochemical characterization of Leishmania major aquaglyceroporin LmAQP1: possible role in volume regulation and osmotaxis. Mol Microbiol. 2007;65(4):1006-1017.

Fischer HG, Eder C. Voltage-gated K+ currents of mouse dendritic cells. FEBS Lett. $1995 ; 373(2): 127-30$. 
Forero ME, Marín M, Corrales A, Llano I, Moreno H, Camacho M. Leishmania amazonensis infection induces changes in the electrophysiological properties of macrophage-like cells. J Membr Biol. 1999;170(2):173-180.

Gagnon E, Duclos S, Rondeau C, Chevet E, Cameron PH, Steele-Mortimer O, Paiement J, Bergeron JJ, Desjardins M. Endoplasmic reticulum-mediated phagocytosis is a mechanism of entry into macrophages. Cell. 2002;110(1):119-131.

Gallin EK. Ion channels in leukocytes. Physiol Rev. 1991;71(3):775-811.

Gallin EK, Gallin JI. Interaction of chemotactic factors with human macrophages. Induction of transmembrane potential changes. J Cell Biol. 1977;75(1):277-89.

Gallin EK, Livengood DR. Demonstration of an electrogenic Na+-K+ pump in mouse spleen macrophages. Am J Physiol. 1983;245(3):C184-8.

Gallin EK, Sheehy PA. Differential expression of inward and outward potassium currents in the macrophage-like cell line J774.1. J Physiol. 1985;369:475-479.

Gamaley IA, Kirpichnikova KM, Klyubin IV. Superoxide release is involved in membrane potential changes in mouse peritoneal macrophages. Free Radic Biol Med. 1998;24(1):168-174.

Garzón C, Stuhmer W, Camacho M Corrientes aniónicas de Leishmania expresadas en ovocitos de Xenopus laevis luego de la inyección de mRNA. Biomedica. 2009;29(S):177-178.

Germain RN. Binding domain regulation of MHC class II molecule assembly, trafficking, fate, and function. Semin Immunol. 1995;7(6):361-372.

Gendelman HE, Ding S, Gong N, Liu J, Ramirez SH, Persidsky Y, Mosley RL, Wang T, Volsky DJ, Xiong H. Monocyte chemotactic protein-1 regulates voltage-gated $\mathrm{K}+$ channels and macrophage transmigration. J Neuroimmune Pharmacol. 2009;4(1):47-59.

Ginsburg H, Stein WD. How many functional transport pathways does Plasmodium falciparum induce in the membrane of its host erythrocyte? Trends Parasitol. 2005;21(3):118-121.

Glaser TA, Mukkada AJ. Proline transport in Leishmania donovani amastigotes: dependence on $\mathrm{pH}$ gradients and membrane potential. Mol Biochem Parasitol. 1992;51(1):1-8.

Gomez MA, Li S, Tremblay ML, and Olivier M. NRAMP-1 Expression Modulates Proteintyrosine Phosphatase Activity in Macrophages Impact on host cell signaling and functions. The J Biol Chem. 2007;282;(50):36190-36198

González U, Pinart M, Rengifo-Pardo M, Macaya A, Alvar J, Tweed JA. Interventions for American cutaneous and mucocutaneous leishmaniasis. Cochrane Database Syst Rev. 2009;(2):CD004834

Gordon S. Alternative activation of macrophages. Nat Rev Immunol. 2003;3:23-35.

Grabe M, Oster G. Regulation of organelle acidity. J Gen Physiol. 2001;117(4):329-344.

Grigore D, Meade JC. A COOH-terminal domain regulates the activity of Leishmania proton pumps LDH1A and LDH1B. Int J Parasitol. 2006;36(4):381-393.

Gourbal B, Sonuc N, Bhattacharjee H, Legare D, Sundar S, Ouellette M, Rosen BP, Mukhopadhyay R. Drug uptake and modulation of drug resistance in Leishmania by an aquaglyceroporin. J Biol Chem. 2004;279(30):31010-31017.

Hackam DJ, Rotstein OD, Zhang W, Gruenheid S, Gros P, and Grinstein S. Host Resistance to Intracellular Infection: Mutation of Natural Resistance-associated Macrophage 
Protein 1(Nramp1) Impairs Phagosomal Acidification. J Exp Med. 1998;188(2):351364.

Hamill OP, Marty A, Neher E, Sakmann B, Sigworth FJ. Improved patch-clamp techniques for high resolution current recording from cells and cell-free membrane patches. Pflügers Archv Eur J Physiol. 1981;391:85-100.

Hanley PJ, Musset B, Renigunta V, Limberg SH, Dalpke AH, Sus R, Heeg KM, PreisigMüller R, Daut J. Extracellular ATP induces oscillations of intracellular Ca2+ and membrane potential and promotes transcription of IL-6 in macrophages. Proc Natl Acad Sci U S A. 2004;101(25):9479-9484.

Hara N, Ichinose M, Sawada M, Imai K, Maeno T. Activation of single Ca2(+)-dependent K+ channel by external ATP in mouse macrophages. FEBS Lett. 1990;267(2):281-284.

Haggie PM, Verkman AS. Cystic fibrosis transmembrane conductance regulatorindependent phagosomal acidification in macrophages. $\mathrm{J}$ Biol Chem. 2007;282(43):31422-31428.

Harding CV. Phagocytic processing of antigens for presentation by MHC molecules. Trends Cell Biol. 1995;5(3):105-109.

Harvey WR, Wieczorekh. Animal plasma membrane energization by chemiosmotic $\mathrm{H}+\mathrm{V}-$ ATPases. J Exp Biol. 1997;200:203-216.

Hattori T, Kajikuri J, Katsuya H, Itoh T. Effects of $\mathrm{H} 2 \mathrm{O} 2$ on membrane potential of smooth muscle cells in rabbit mesenteric resistance artery. Eur J Pharmacol. 2003;464(23):101-109.

Heinzen RA, Hackstadt T. The Chlamydia trachomatis parasitophorous vacuolar membrane is not passively permeable to low-molecular-weight compounds. Infect Immun. 1997;65(3):1088-1094.

Henriques C, Atella GC, Bonilha VL, de Souza W. Biochemical analysis of proteins and lipids found in parasitophorous vacuoles containing Leishmania amazonensis. Parasitol Res. 2003;89:123-133.

Holevinsky KO, Jow F, Nelson DJ. Elevation in intracellular calcium activates both chloride and proton currents in human macrophages. J Membr Biol. 1994;140(1):13-30.

Holevinsky KO, Nelson DJ. Simultaneous detection of free radical release and membrane current during phagocytosis. J Biol Chem. 1995;270(14):8328-8336.

Holevinsky KO, Nelson DJ. Membrane capacitance changes associated with particle uptake during phagocytosis in macrophages. Biophys J. 1998;75(5):2577-2586.

Hoyos M, Niño A, Camargo M, Díaz JC, León S, Camacho M. Separation of Leishmaniainfected macrophages by step-SPLITT fractionation. J Chromatogr B Analyt Technol Biomed Life Sci. 2009;877(29):3712-3718.

Horta MF. Pore-forming proteins in pathogenic protozoan parasites. Trends Microbiol. 1997;5(9):363-366.

Huynh C, Sacks DL, Andrews NW. A Leishmania amazonensis ZIP family iron transporter is essential for parasite replication within macrophage phagolysosomes. J Exp Med. 2006;203(10):2363-2375.

Huynh C, Andrews NW. Iron acquisition within host cells and the pathogenicity of Leishmania. Cell Microbiol. 2008;10(2):293-300.

Ichinose M, Hara N, Sawada M, Maeno T. Activation of K+ current in macrophages by platelet activating factor. Biochem Biophys Res Commun. 1992;182(1):372-378. 
Idone V, Tam C, Andrews NW. Two-way traffic on the road to plasma membrane repair. Trends Cell Biol. 2008;18(11):552-559.

Inbar E, Canepa GE, Carrillo C, Glaser F, Suter Grotemeyer M, Rentsch D, Zilberstein D, Pereira CA. Lysine transporters in human trypanosomatid pathogens. Amino Acids. 2010. [Epub ahead of print]

Informe epidemiológico nacional 2009, Instituto Nacional de Salud, Bogotá, Colombia

Jabado N, Jankowski A, Dougaparsad S, Picard V, Grinstein S, and Gros P. Natural Resistance to Intracellular Infections: Natural Resistance-associated Macrophage Protein 1(NRAMP1) Functions as a pH-dependent Manganese Transporter at the Phagosomal Membrane. J Exp Med. 2000;192(9): 1237-1247.

Jacques I, Andrews NW, Huynh C. Functional characterization of LIT1, the Leishmania amazonensis ferrous iron transporter. Mol Biochem Parasitol. 2010;170(1):28-36.

Jentsch TJ, Neagoe I, Scheel O. CLC chloride channels and transporters. Curr Opin Neurobiol. 2005 Jun;15(3):319-325.

Jentsch TJ. Chloride and the endosomal-lysosomal pathway: emerging roles of CLC chloride transporters. Physiol. 2007;578(Pt 3):633-640.

Jiang S, Anderson SA, Winget GD, Mukkada AJ. Plasma membrane $\mathrm{K}+/ \mathrm{H}(+)$-ATPase from Leishmania donovani. J Cell Physiol. 1994;159(1):60-66.

Judge SI, Montcalm-Mazzilli E, Gallin EK. IKir regulation in murine macrophages: whole cell and perforated patch studies. Am J Physiol. 1994; 267(6 Pt 1):C1691-1698.

Lagos M LF, Moran O, Camacho M. Leishmania amazonensis: Anionic currents expressed in oocytes upon microinjection of mRNA from the parasite. Exp Parasitol. 2007;116(2):163-170.

Lamb FS, Moreland JG, Miller FJ Jr. Electrophysiology of reactive oxygen production in signaling endosomes. Antioxid Redox Signal. 2009;11(6):1335-1347.

Liew FY, Xu D, Chan WL. Immune effector mechanism in parasitic infections. Immunol Lett. 1999;65(1-2):101-104.

Liu JH, Bijlenga P, Fischer-Lougheed J, Occhiodoro T, Kaelin A, Bader CR, Bernheim L. Role of an inward rectifier $\mathrm{K}+$ current and of hyperpolarization in human myoblast fusion. J Physiol. 1998;510(Pt2):467-476.

Liu C, Cotten JF, Schuyler JA, Fahlman CS, Au JD, Bickler PE, Yost CS. Protective effects of TASK-3 (KCNK9) and related 2P K channels during cellular stress. Brain Res. 2005;1031(2):164-73.

LeFurgey A, Ingram P, Blum JJ. Compartmental responses to acute osmotic stress in Leishmania major result in rapid loss of $\mathrm{Na}+$ and $\mathrm{Cl}$-. Comp Biochem Physiol A Mol Integr Physiol. 2001;128(2):385-394.

LeFurgey A, Gannon M, Blum J, Ingram P. Leishmania donovani amastigotes mobilize organic and inorganic osmolytes during regulatory volume decrease. J Eukaryot Microbiol. 2005;52(3):277-289.

Lingelbach K, Joiner KA. The parasitophorous vacuole membrane surrounding Plasmodium and Toxoplasma: an unusual compartment in infected cells. J Cell Sci. 1998;111(Pt11):1467-1475.

Link TM, Park U, Vonakis BM, Raben DM, Soloski MJ, Caterina MJ. TRPV2 has a pivotal role in macrophage particle binding and phagocytosis. Nat Immunol. 2010;11(3):232-239. 
Lisi S, Sisto M, Acquafredda A, Spinelli R, Schiavone M, Mitolo V, Brandonisio O, Panaro M. Infection with Leishmania infantum Inhibits actinomycin D-induced apoptosis of human monocytic cell line U-937. J Eukaryot Microbiol. 2005;52(3):211-217.

Lozano Y, Gomez C, Posada ML, Camacho M. Canales de cloruro CLC de Leishmania. Biomedica. 2009;29(S):184.

Lozano Y, Posada ML, Camacho M Lozano Jiménez YY, Posada ML, Forero ME, Camacho M. El canal de cloruro putativo LbrM01_V2.0210 de Leishmania genera corrientes de cloruro sensibles a pH y osmolaridad. Biomedica. 2011;31(S3):23-205:106.

Lu HG, Zhong L, Chang KP, Docampo R. Intracellular Ca2+ pool content and signaling and expression of a calcium pump are linked to virulence in Leishmania mexicana amazonesis amastigotes. J Biol Chem. 1997;272(14):9464-9473.

Mackenzie AB, Chirakkal H, North RA. Kv1.3 potassium channels in human alveolar macrophages. Am J Physiol Lung Cell Mol Physiol. 2003;285(4):L262-268.

Meade JC, Shaw J, Lemaster S, Gallagher G, Stringer JR. Structure and expression of a tandem gene pair in Leishmania donovani that encodes a protein structurally homologous to eucaryotic cation-transporting ATPases. Mol Cell Biol. 1987;7(11):3937-3946.

Maharjan M, Singh S, Chatterjee M, Madhubala R. Role of aquaglyceroporin (AQP1) gene and drug uptake in antimony-resistant clinical isolates of Leishmania donovani. Am J Trop Med Hyg. 2008;79(1):69-75.

Mandal D, Mukherjee T, Sarkar S, Majumdar S, Bhaduri A. The plasma-membrane Ca2+ATPase of Leishmania donovani is an extrusion pump for Ca2+. Biochem J. 1997;322(Pt1):251-257.

Marchesini N, Docampo R-A plasma membrane P-type H(+)-ATPase regulates intracellular pH in Leishmania mexicana amazonensis. Mol Biochem Parasitol. 2002;119(2):225236.

Martin AM, Liu T, Lynn BC, Sinai AP. The Toxoplasma gondii parasitophorous vacuole membrane: transactions across the border. J Eukaryot Microbiol. 2007;54(1):25-28.

Martin RE, Ginsburg H, Kirk K. Membrane transport proteins of the malaria parasite. Mol Microbiol. 2009;74(3):519-528.

McCann FV, Keller TM, Guyre PM. Ion channels in human macrophages compared with the U-937 cell line. J Membr Biol. 1987;96(1):57-64.

McCann FV, Cole JJ, Guyre PM, Russell JA. Action potentials in macrophages derived from human monocytes. Science. 1983; 219(4587):991-993.

McKinney LC, Gallin EK. Inwardly rectifying whole-cell and single-channel K currents in the murine macrophage cell line J774.1. J Membr Biol. 1988;103(1):41-53.

McKinney LC, Gallin EK. Effect of adherence, cell morphology, and lipopolysaccharide on potassium conductance and passive membrane properties of murine macrophage J774.1 cells. J Membr Biol. 1990;116(1):47-56.

McKinney LC, Gallin EK. G-protein activators induce a potassium conductance in murine macrophages. J Membr Biol. 1992;130(3):265-276.

McNally AK, Anderson JM. Multinucleated giant cell formation exhibits features of phagocytosis with participation of the endoplasmic reticulum. Exp Mol Pathol. 2005;79(2):126-135. 
Meirelles MNL, De Souza W. Interaction of lysosomes with endocytic vacuoles in macrophages simultaneously infected with Trypanosoma cruzi and Toxoplasma gondii. J Submicrosc Cytol. 1983;(15):889-896

Miledi R, Parker I, Woodward RM. Membrane currents elicited by divalent cations in Xenopus oocytes. J Physiol. 1989;417:173-195.

Moreno SN, Docampo R. Calcium regulation in protozoan parasites. Curr Opin Microbiol. 2003;6(4):359-364

Mosser DM, Edwards JP. Exploring the full spectrum of macrophage activation. Nat Rev Immunol. 2008;8(12):958-969.

Mukherjee T, Mandal D, Bhaduri A. Leishmania plasma membrane Mg2+-ATPase is a $\mathrm{H}+/ \mathrm{K}+$-antiporter involved in glucose symport. Studies with sealed ghosts and vesicles of opposite polarity. J Biol Chem. 2001;276(8):5563-5569.

Murray RZ, Wylie FG, Khromykh T, Hume DA, Stow JL. Syntaxin 6 and Vti1b form a novel SNARE complex, which is up-regulated in activated macrophages to facilitate exocytosis of tumor necrosis Factor-alpha.J Biol Chem. 2005a;280(11):10478-10483.

Murray RZ, Kay JG, Sangermani DG, Stow JL. A role for the phagosome in cytokine secretion. Science. 2005b;310(5753):1492-1495.

Nelson DJ, Jow B, Popovich KJ. Whole-cell currents in macrophages: II. Alveolar macrophages. J Membr Biol. 1990;117(1):45-55.

Noronha FS, Cruz JS, Beirão PS, Horta MF. Macrophage damage by Leishmania amazonensis cytolysin: evidence of pore formation on cell membrane. Infect Immun. 2000;68(8):4578-4584.

Novarino G, Weinert S, Rickheit G, Jentsch TJ. Endosomal chloride-proton exchange rather than chloride conductance is crucial for renal endocytosis. Science. 2010;328(5984):1398-1401.

Ogbunude PO, Dzimiri MM. Expression of a channel-like pathway for adenosine transport in Leishmania donovani promastigotes. Int J Parasitol. 1993;23(6):803-807.

Olivier M. Modulation of Host cell Intracellular Ca2+. Parasitol Today. 1996;12(4):145-150.

Ouellette M, Legare D, Papadopoulou B. Multidrug resistance and ABC transporters in parasitic protozoa. J Mol Microbiol Biotechnol. 2001;3(2):201-206.

Ouellette M, Drummelsmith J, El-Fadili A, Kündig C, Richard D, Roy G. Pterin transport and metabolism in Leishmania and related trypanosomatid parasites. Int $\mathrm{J}$ Parasitol. 2002;32(4):385-398.

Panyi G, Varga Z, Gáspár R. Ion channels and lymphocyte activation. Immunol Lett. 2004;92(1-2):55-66.

Park SA, Lee YC, Ma TZ, Park JA, Han MK, Lee HH, Kim HG, Kwak YG. hKv1.5 channels play a pivotal role in the functions of human alveolar macrophages. Biochem Biophys Res Commun. 2006(28);346(2):567-571.

Perez C, Hoyos M, Camacho M. Aislamiento de la vacuola parasitófora que contiene al parásito Leishmania amazonensis mediante la técnica SPLITT. Biomedica. 2007; 27(S2):144-145.

Perez C Estudio de corrientes iónicas de la membrana de la vacuola parasitófora que contiene al parásito Leishmania amazonensis. Masters thesis, Departamento de Química, Facultad de Ciencias, Universidad Nacional de Colombia; 2008.

Perez C, Stuhmer W, Camacho M Canales de cloruro y potasio en la membrana de la vacuola parasitófora de Leishmania amazonensis. Biomedica. 2009;29(S)193-194. 
Philosoph H, Zilberstein D. Regulation of intracellular calcium in promastigotes of the human protozoan parasite Leishmania donovani. J Biol Chem. 1989;264(18):1042010424.

Pitt A, Mayorga LS, Stahl PD, Schwartz AL. Alterations in the protein composition of maturing phagosomes. J Clin Invest. 1992;90(5):1978-1983.

Ponte-Sucre A, Campos Y, Fernandez M, Moll H, Mendoza-León A. Leishmania sp.: growth and survival are impaired by ion channel blockers. Exp Parasitol. 1998;88(1):11-19.

Prina E, Antoine JC, Wiederanders B, Kirschke H. Localization and activity of various lysosomal proteases in Leishmania amazonensis-infected macrophages. Infect Immun. 1990;58(6):1730-1737.

Quintana E, Torres Y, Alvarez C, Rojas A, Forero ME, Camacho M. Changes in macrophage membrane properties during early Leishmania amazonensis infection differ from those observed during established infection and are partially explained by phagocytosis. Exp Parasitol. 2010;124(3):258-264.

Rabinovitch M, Topper G, Cristello P, Rich A. Receptor-mediated entry of peroxidases into the parasitophorous vacuoles of macrophages infected with Leishmania Mexicana amazonensis. J Leukoc Biol. 1985;37(3):247-261.

Randriamampita C, Trautmann A. Ionic channels in murine macrophages. J Cell Biol. 1987;105(2):761-769.

Randriamampita C, Trautmann A. Biphasic increase in intracellular calcium induced by platelet-activating factor in macrophages. FEBS Lett. 1989;249(2):199-206.

Randriamampita C, Bismuth G, Trautmann A. Ca(2+)-induced Ca2+ release amplifies the $\mathrm{Ca} 2+$ response elicited by inositol trisphosphate in macrophages. Cell Regul. 1991;2(7):513-522.

Rodrigues CO, Scott DA, Docampo R. Presence of a vacuolar H+-pyrophosphatase in promastigotes of Leishmania donovani and its localization to a different compartment from the vacuolar H+-ATPase. Biochem J. 1999;340(Pt3):759-766.

Russell DG, Xu S, Chakraborty P. Intracellular trafficking and the parasitophorous vacuole of Leishmania mexicana-infected macrophages. J Cell Sci. 1992;103:1193-1210.

Russell DG. Mycobaterium and Leishmania: stowaways in the endosomal network. Trends Cell Biol. 1995;5:125-128

Schaible UE, Schlesinger PH, Steinberg TH, Mangel WF, Kobayashi T, Russell DG. Parasitophorous vacuoles of Leishmania mexicana acquire macromolecules from the host cell cytosol via two independent routes. J Cell Sci. 1999;112(Pt5):681-693.

Scheel O, Zdebik AA, Lourdel S, Jentsch TJ. Voltage-dependent electrogenic chloride/proton exchange by endosomal CLC proteins. Nature. 2005;436(7049):424427.

Schwab JC, Beckers CJ, Joiner KA. The parasitophorous vacuole membrane surrounding intracellular Toxoplasma gondii functions as a molecular sieve. Proc Natl Acad Sci U S A. 1994;18;91(2):509-513.

Shaked-Mishan P, Suter-Grotemeyer M, Yoel-Almagor T, Holland N, Zilberstein D, Rentsch D. A novel high-affinity arginine transporter from the human parasitic protozoan Leishmania donovani. Mol Microbiol. 2006;60(1):30-38.

Singh A, Mandal D. A novel sucrose/H+ symport system and an intracellular sucrase in Leishmania donovani. Int J Parasitol. 2011;41(8):817-826. 
Scott KD, Stafford JL, Galvez F, Belosevic M, Goss GG. Plasma membrane depolarization reduces nitric oxide (NO) production in P388D.1 macrophage-like cells during Leishmania major infection. Cell Immunol. 2003;222(1):58-68.

Sousa-Franco J, Araújo-Mendes E, Silva-Jardim I, L-Santos J, Faria DR, Dutra WO, Horta MF. Infection-induced respiratory burst in BALB/c macrophages kills Leishmania guyanensis amastigotes through apoptosis: possible involvement in resistance to cutaneous leishmaniasis. Microbes Infect. 2006;8(2):390-400.

Shepherd, VL, Stahl, PD, Bernd P, Rabinovitch, M. Receptor-mediated entry of betaglucuronidase into the parasitophorous vacuoles of macrophages infected with Leishmania mexicana amazonensis. J Exp Med. 1983;157(5):1471-1482-1492.

Staines HM, Alkhalil A, Allen RJ, De Jonge HR, Derbyshire E, Egée S, Ginsburg H, Hill DA, Huber SM, Kirk K, Lang F, Lisk G, Oteng E, Pillai AD, Rayavara K, Rouhani S, Saliba KJ, Shen C, Solomon T, Thomas SL, Verloo P, Desai SA. Electrophysiological studies of malaria parasite-infected erythrocytes: current status. Int J Parasitol. 2007;37(5):475-482.

Steinberg TH, Newman AS, Swanson JA, Silverstein SC. ATP4- permeabilizes the plasma membrane of mouse macrophages to fluorescent dyes. J Biol Chem. 1987a;262(18):8884-8888.

Steinberg TH, Newman AS, Swanson JA, Silverstein SC. Macrophages possess probenecidinhibitable organic anion transporters that remove fluorescent dyes from the cytoplasmic matrix. J Cell Biol. 1987b;105(6 Pt 1):2695-2702.

Steinberg TH, Mangel WF, Steinberg BE, Huynh KK, Brodovitch A, Jabs S, Stauber T, Jentsch TJ, Grinstein S. A cation counterflux supports lysosomal acidification. J Cell Biol. 2010;189(7):1171-1186.

Stiles JK, Kucerova Z, Sarfo B, Meade CA, Thompson W, Shah P, Xue L, Meade JC. Identification of surface-membrane P-type ATPases resembling fungal $\mathrm{K}(+)$ - and $\mathrm{Na}(+)$-ATPases, in Trypanosoma brucei, Trypanosoma cruzi and Leishmania donovani. Ann Trop Med Parasitol. 2003;97(4):351-366.

Sturgill-Koszycki S, Schlesinger PH, Chakraborty P, Haddix PL, Collins HL, Fok AK, Allen RD, Gluck SL, Heuser J, Russell DG. Lack of acidification in Mycobacterium phagosomes produced by exclusion of the vesicular proton-ATPase. Science. 1994;263(5147):678-681.

Stühmer W: Electrophysiological recording from Xenopus oocytes in Rudy B, Iverson L (eds): Methods in Enzymology. Academic Press. 1992;207:318-339.

Tanabe K. Ion metabolism in malaria-infected erythrocytes. Blood Cells. 1990;16(2-3):437-49.

Tardieux I, Nathanson MH, Andrews NW. Role in host cell invasion of Trypanosoma cruziinduced cytosolic-free Ca2+ transients. J Exp Med. 1994;179(3):1017-1022.

ter Kulle BH. Glucose and proline transport in kinetoplastids. Parasitol Today. 1993;9(6):206210.

Tetaud E, Bringaud F, Chabas S, Barrett MP, Baltz T. Characterization of glucose transport and cloning of a hexose transporter gene in Trypanosoma cruzi. Proc Natl Acad Sci U S A. 1994;91(17):8278-8282.

Vargas R, Botero L, Lagos L, Camacho M. Bufo marinus oocytes as a model for ion channel protein expression and functional characterization with electrophysiological studies. Cel Physiol Biochem. 2004;14(4-6):197-202. 
Veras PS, de Chastellier C, Rabinovitch M. Transfer of zymosan (yeast cell walls) to the parasitophorous vacuoles of macrophages infected with Leishmania amazonensis. J Exp Med. 1992;176(3):639-646.

Veras PS, de Chastellier C, Moreau MF, Villiers V, Thibon M, Mattei D, Rabinovitch M. Fusion between large phagocytic vesicles: targeting of yeast and other particulates to phagolysosomes that shelter the bacterium Coxiella burnetii or the protozoan Leishmania amazonensis in Chinese hamster ovary cells. J Cell Sci. 1994;107 107(Pt11):3065-3076.

Veras PS, Moulia C, Dauguet C, Tunis CT, Entry and survival of Leishmania amazonensis amastigotes within phagolysosome-like vacuoles that shelter Coxiella burnetii in Chinese hamster ovary cells. Thibon $M$, Rabinovitch M. Infect Immun. 1995;63(9):3502-3506.

Veras PS, Topilko A, Gouhier N, Moreau MF, Rabinovitch M, Pouchelet M. Fusion of Leishmania amazonensis parasitophorous vacuoles with phagosomes containing zymosan particles: cinemicrographic and ultrastructural observations. Braz J Med Biol Res. 1996;29(8):1009-1018.

Vercesi AE, Rodrigues CO, Catisti R, Docampo R. Presence of a $\mathrm{Na}(+) / \mathrm{H}(+)$ exchanger in acidocalcisomes of Leishmania donovani and their alkalization by anti-leishmanial drugs. FEBS Lett. 2000;473(2):203-206.

Vicente R, Escalada A, Coma M, Fuster G, Sánchez-Tilló E, López-Iglesias C, Soler C, Solsona C, Celada A, Felipe A. Differential voltage-dependent K+ channel responses during proliferation and activation in macrophages. J Biol Chem. 2003;278(47):46307-46320.

Vicente R, Escalada A, Soler C, Grande M, Celada A, Tamkun MM, Solsona C, Felipe A. Pattern of $\mathrm{Kv}$ beta subunit expression in macrophages depends upon proliferation and the mode of activation. J Immunol. 2005;174(8):4736-4744.

Vicente R, Escalada A, Villalonga N, Texidó L, Roura-Ferrer M, Martín-Satué M, LópezIglesias C, Soler C, Solsona C, Tamkun MM, Felipe A. Association of Kv1.5 and Kv1.3 contributes to the major voltage-dependent $\mathrm{K}+$ channel in macrophages. J Biol Chem. 2006;281(49):37675-37685.

Vicente R, Villalonga N, Calvo M, Escalada A, Solsona C, Soler C, Tamkun MM, Felipe A. Kv1.5 association modifies Kv1.3 traffic and membrane localization. J Biol Chem. 2008;283(13):8756-8764.

Vieira L, Lavan A, Dagger F, Cabantchik ZI. The role of anions in $\mathrm{pH}$ regulation of Leishmania major promastigotes. J Biol Chem. 1994;269(23):16254-16259.

Vieira LL, Cabantchik ZI. Amino acid uptake and intracellular accumulation in Leishmania major promastigotes are largely determined by an $\mathrm{H}(+)$-pump generated membrane potential. Mol Biochem Parasitol. 1995;75(1):15-23.

Vieira LL, Lafuente E, Gamarro F, Cabantchik Z. An amino acid channel activated by hypotonically induced swelling of Leishmania major promastigotes. Biochem J. 1996;319:691-697.

Vieira LL, Lafuente E, Blum J, Cabantchik ZI. Modulation of the swelling-activated amino acid channel of Leishmania major promastigotes by protein kinases. Mol Biochem Parasitol. 1997;90(2):449-461.

Vignery A. Macrophage fusion: the making of osteoclasts and giant cells. J Exp Med. 2005;202(3):337-340. 
Villalonga N, Escalada A, Vicente R, Sánchez-Tilló E, Celada A, Solsona C, Felipe A. Kv1.3/Kv1.5 heteromeric channels compromise pharmacological responses in macrophages. Biochem Biophys Res Commun. 2007;352(4):913-918.

Villalonga N, David M, Bielanska J, Vicente R, Comes N, Valenzuela C, Felipe A. Immunomodulation of voltage-dependent $\mathrm{K}+$ channels in macrophages: molecular and biophysical consequences. J Gen Physiol. 2010;135(2):135-147.

Vinet AF, Fukuda M, Turco SJ, Descoteaux A. The Leishmania donovani lipophosphoglycan excludes the vesicular proton-ATPase from phagosomes by impairing the recruitment of synaptotagmin V. PLoS Pathog. 2009;5(10):e1000628.

Weinert S, Jabs S, Supanchart C, Schweizer M, Gimber N, Richter M, Rademann J, Stauber T, Kornak U, Jentsch TJ. Lysosomal pathology and osteopetrosis upon loss of $\mathrm{H}+-$ driven lysosomal Cl- accumulation. Science. 2010;328(5984):1401-1403.

Zilberstein D, Dwyer DM. Protonmotive force-driven active transport of D-glucose and Lproline in the protozoan parasite Leishmania donovani. Proc Natl Acad Sci U S A. 1985;82(6):1716-1720.

Zilberstein D. Transport of Nutrients and Ions across Membranes of Trypanosomatid Parasites. In Advances in Parasitology. 1993(32):261-291.

Zilberstein D, Shapira M. The role of $\mathrm{pH}$ and temperature in the development of Leishmania parasites. Annu Rev Microbiol. 1994;48:449-470. 


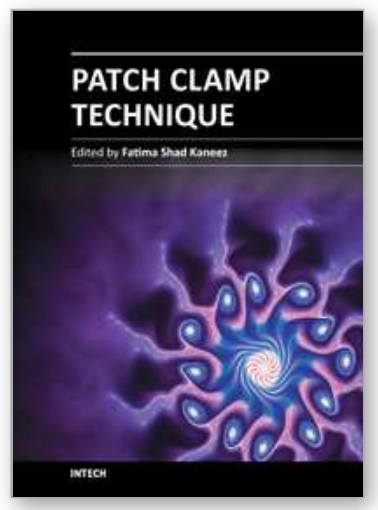

\author{
Patch Clamp Technique \\ Edited by Prof. Fatima Shad Kaneez
}

ISBN 978-953-51-0406-3

Hard cover, 356 pages

Publisher InTech

Published online 23, March, 2012

Published in print edition March, 2012

This book is a stimulating and interesting addition to the collected works on Patch clamp technique. Patch Clamping is an electrophysiological technique, which measures the electric current generated by a living cell, due to the movement of ions through the protein channels present in the cell membrane. The technique was developed by two German scientists, Erwin Neher and Bert Sakmann, who received the Nobel Prize in 1991 in Physiology for this innovative work. Patch clamp technique is used for measuring drug effect against a series of diseases and to find out the mechanism of diseases in animals and plants. It is also most useful in finding out the structure function activities of compounds and drugs, and most leading pharmaceutical companies used this technique for their drugs before bringing them for clinical trial. This book deals with the understanding of endogenous mechanisms of cells and their receptors as well as advantages of using this technique. It covers the basic principles and preparation types and also deals with the latest developments in the traditional patch clamp technique. Some chapters in this book take the technique to a next level of modulation and novel approach. This book will be of good value for students of physiology, neuroscience, cell biology and biophysics.

\title{
How to reference
}

In order to correctly reference this scholarly work, feel free to copy and paste the following:

Marcela Camacho (2012). Electrical Membrane Properties in the Model Leishmania-Macrophage, Patch Clamp Technique, Prof. Fatima Shad Kaneez (Ed.), ISBN: 978-953-51-0406-3, InTech, Available from: http://www.intechopen.com/books/patch-clamp-technique/electrical-membrane-properties-in-the-modelleishmania-macrophage

\section{INTECH}

open science | open minds

\section{InTech Europe}

University Campus STeP Ri

Slavka Krautzeka 83/A

51000 Rijeka, Croatia

Phone: +385 (51) 770447

Fax: +385 (51) 686166

www.intechopen.com

\section{InTech China}

Unit 405, Office Block, Hotel Equatorial Shanghai

No.65, Yan An Road (West), Shanghai, 200040, China 中国上海市延安西路65号上海国际贵都大饭店办公楼 405 单元

Phone: +86-21-62489820

Fax: $+86-21-62489821$ 
(C) 2012 The Author(s). Licensee IntechOpen. This is an open access article distributed under the terms of the Creative Commons Attribution 3.0 License, which permits unrestricted use, distribution, and reproduction in any medium, provided the original work is properly cited. 